\title{
Shear strength analysis of slabs without transverse reinforcement under concentrated loads according to ABNT NBR 6118:2014
}

\author{
Análise de resistência à força cortante em lajes \\ sem armadura transversal sob cargas parcialmente \\ distribuídas segundo a ABNT NBR 6118:2014
}

\author{
A. M. D. SOUSA \\ alex dantas@usp.br \\ https://orcid.org/0000-0003-0424-4080 \\ M. K. EL DEBS a \\ mkdebs@sc.usp.br \\ https://orcid.org/0000-0001-5955-7936
}

\begin{abstract}
Concentrated loads in slabs without transverse reinforcement, usual in highway bridges, result in the horizontal spreading of the shear force towards the supports, situation in which not all the slab width contributes in the shear strength. Based on this, the analytical models of shear strength and punching capacity in slabs may not be suitable to deal with this loading. Since this topic is not widely discussed in the national technical literature, the paper aims to present contributions to these analyses with a focus on the accuracy level of the shear strength analytical models recommended by ABNT NBR 6118:2014. Therefore, the models available in the Brazilian code were applied to an experimental database with 118 test results and the results obtained by the Brazilian and European codes were compared. The results demonstrated that, as presented in the Brazilian code, shear strength model in one-way slabs can lead to unsafe resistance predictions while the punching capacity model can lead to very conservative predictions. From the analysis, it is concluded that considering the reduction of the shear force, in the case of loads distributed in small areas close to the support in slabs, and the use of more suitable procedures to define the effective width, it is possible to improve the level of accuracy of relations between experimental and theoretical values, but this still leads to high percentages of unsafe predictions of resistance $(>40 \%)$.
\end{abstract}

Keywords: shear strength, slabs without transverse reinforcement, concentrated load, load close to support.

\section{Resumo}

A solicitação por cargas parcialmente distribuídas em lajes sem armadura transversal, frequente em tabuleiros de pontes, resulta na propagação horizontal da força cortante em direção aos apoios, situação na qual nem toda a largura da laje é mobilizada. Por esta razão, os modelos de resistência à força cortante de vigas e de resistência à punção em lajes podem não se adequar ao tratamento do problema. Uma vez que este ainda é um tema pouco discutido na literatura nacional, o artigo tem por objetivo apresentar contribuições à análise deste tipo de problema com enfoque no nível de precisão dos modelos de cálculo de resistência à força cortante preconizados pela ABNT NBR 6118:2014. Para isto aplicaram-se os modelos disponíveis na norma brasileira a uma base de dados experimentais com 118 resultados de ensaios e compararam-se os resultados obtidos pelo código brasileiro e europeu. Os resultados demonstraram que, na forma como disposta, as formulações brasileiras de resistência à força cortante em lajes unidirecionais podem conduzir a previsões inseguras de resistência e que a formulação de resistência à punção pode conduzir a previsões excessivamente conservadoras. Das análises realizadas conclui-se que com a consideração de redução da força cortante solicitante, no caso de cargas distribuídas em pequenas áreas próximas do apoio em lajes, e utilização de procedimentos mais apropriados de definição da largura colaborante é possível melhorar a correlação entre valores experimentais e teóricos, mas ainda resulta em percentuais elevados de previsões inseguras de resistência $(>40 \%)$.

Palavras-chave: resistência à força cortante, lajes sem armadura transversal, carga parcialmente distribuída, carga próxima do apoio. 


\section{Introduction}

The shear strength in reinforced concrete elements without transverse reinforcement is usually analyzed under two approaches: (i) one-way shear (beam shear) and (ii) two-way shear (punching capacity) (Figure 1a). However, in the case of partially distributed loads on small areas (concentrated loads) close to supports, not
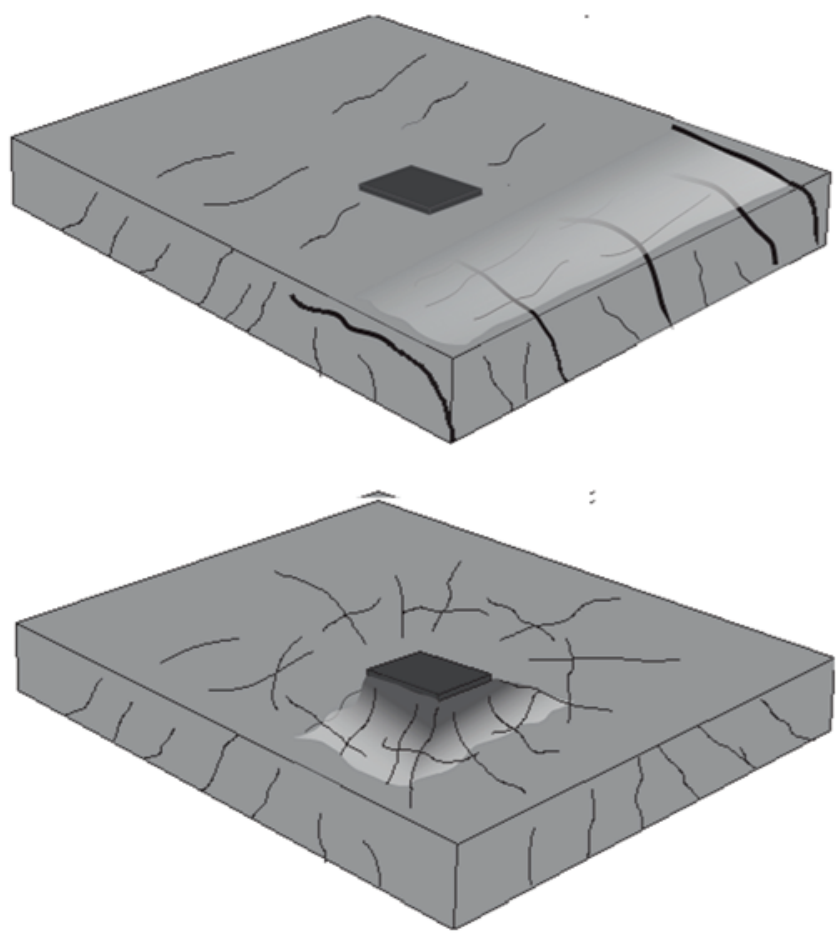

a) the entire width of the slab is mobilized. In this type of load, the load spreads horizontally towards the support, which explains why the failure mode due to this type of load usually occurs with inclined cracks in relation to the main axis of the slabs (Figure 1b). For this reason, this problem has been associated to a transition zone between one-way shear force models (cracks parallel to the support) and two-way shear models (tangential and radial cracks) [1].
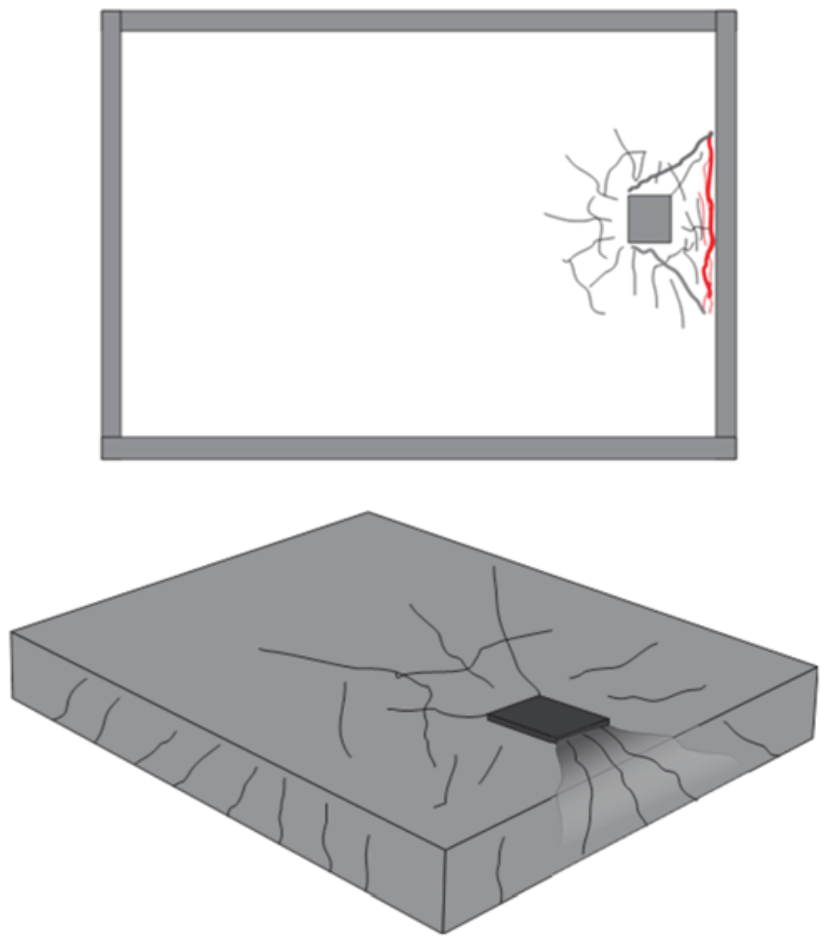

b)

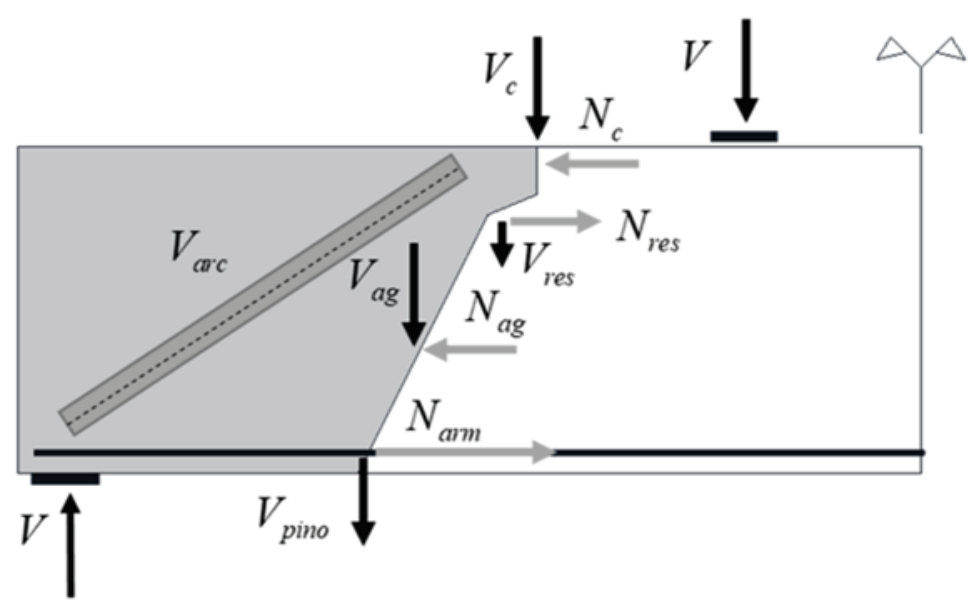

c)

\section{Figure 1}

a) Failure mode by one-way shear in beams or slabs strips and two way shear by punching on slabs;

b) failure mode as wide beam and c) Usual shear transfer mechanisms 
The shear strength analysis, in slabs without transverse reinforcement, has been widely studied in the last decades. Among the reasons for this can be mentioned the complexity of the mechanisms involved and the challenge to formalize a largely recognized model in the scientific community to quantify the influence of these mechanisms, such as (i) capacity of the concrete in the compression zone $\mathrm{V}_{\mathrm{c}}$, (ii) residual tension at crack $\mathrm{V}_{\text {res }}$, (iii) aggregate interlock between cracked surfaces $V_{a g}$, (iv) dowel action of the longitudinal reinforcement $\mathrm{V}_{\text {dowel }}$ and $(\mathrm{V})$ arching action $\mathrm{V}_{\text {arc }}[2,3]$ (Figure 1c).

However, in the last decade the analyses involving shear strength in slabs under partially distributed loads have acquired more attention. This has occurred mainly due to the updating of design codes and manuals for bridges, which, due to advances in calculation procedures and increase in traffic on highways, have resulted in increased design loads and calculation models more conservatives, respectively. [4]. The two aspects cited have resulted, for example, in non-approval in the evaluations of shear strength in about 600 bridges in the Netherlands, which led to the re-evaluation of the calculation procedures used in the country [5]. Since in most of the mentioned structures no risk of collapse was identified, it was concluded that additional mechanisms of shear strength were being mobilized, such as the arching effect already known in the case of beams and that the Dutch model of effective width needed to be reviewed.

Different experimental studies have been performed around the world in an attempt to better understand the shear strength in the case of the partially distributed load near the supports. Among the investigated parameters are the influence of longitudinal reinforcement types (smooth or ribbed bars), type of support (elastomeric or rigid) [6] and the effect of axial stresses on the shear strength of the slabs Other studies have investigated the influence, on the shear strength and the distribution of reactions along the support, of parameters such as the location of the load, presence of ducts and repeated actions (fatigue) in cantilever slabs $[1,8]$. Other studies have investigated the influence, on the shear strength and the distribution of reactions along the support, of parameters such as the location of the load, presence of ducts and repeated actions (fatigue) in cantilever slabs $[1,8]$, besides the degree of clamping in the supports and the static system of slabs $[9,10]$. In all these investigations, European or American codes/ manuals evaluations were performed on the level of prediction of these analytical models. However, this type of loading (partially distributed load close to the support) is still a little studied issue in Brazil, and as a result no research was found about the precision level of the calculation procedures prescribed in ABNT NBR 6118: 2014 [11].

The development of refined numerical models, incorporating physical and geometric nonlinearities of materials, allowed a more detailed analysis of the shear strength [12] but they still have limited application to professional practice in engineering due to more complexity. For this reason, the development of analytical models that attempt to provide more accurate predictions of shear strength, by means of a consistent theoretical background and accessible application in the design practice, still stand out. In this way, the paper aims to present an evaluation of the Brazilian standard with regard to possible approaches for this type of request, in reinforced concrete slabs without transversal reinforcement, and to discuss aspects related to other codes that can be implemented in the Brazilian code in order to make it more consistent for this type of problem. For this purpose, an experimental database with 118 test results was used, already evaluated accordingly to the European code [13]. Thus the calculation models provided for the ABNT NBR 6118:2014 [11] were assessed on two approaches: (i) one-way shear strength and (ii) punching capacity.

\section{Approaches to shear strength according to ABNT NBR 6118:2014}

Most design codes present one-way shear strength models based on slender, lightly reinforced and four-point loaded, whereas punching capacity formulations are based on test of axi-symmetric loaded slabs in the center. [3]. In this way, it is observed that the experiments from which the theories of shear strength in slabs were formulated are not suited to solve particular case loads, such as that of the partially distributed load close to the support.

The ABNT NBR 6118:2014 [11] deals with shear strength under two approaches: (i) verification of resistance in slabs or linear elements by a one-way shear model and (ii) verification of punching capacity at critical perimeter. In this item are presented the equations and recommendations for verification of shear strength according to the Brazilian standard and discussed some aspects for application of the calculation models to the case of request studied.

\subsection{One-way model to slabs without transverse reinforcement}

The shear force strength $V_{R d, 6118}$ in strips of reinforced concrete slabs without transverse reinforcement is determined according to item 19.4.1 of ABNT NBR 6118: 2014 [11] through the equations:

$\mathrm{V}_{\mathrm{Rd} .6118}=\left[\tau_{\mathrm{Rd}} \cdot \mathrm{k} \cdot\left(1,2+40 \cdot \rho_{\mathrm{I}}\right)+0,15 \cdot \sigma_{\mathrm{Cp}}\right] \cdot b_{w} \cdot d$

$\tau_{\mathrm{Rd}}=0,25 \cdot \mathrm{f}_{\mathrm{ctd}}$

$f_{c t d}=f_{c t k, \text { inf }} / \gamma_{c}$

$f_{c t k, i n f}=0,7 \cdot f_{c t m}$

$f_{\mathrm{ctm}}=\left\{\begin{array}{l}0,3 \cdot \sqrt[3]{f_{\mathrm{ck}}^{2}} \text { valid for concretes until class } \mathrm{C50}\left(\mathrm{f}_{\mathrm{ck}} \text { em MPa) }\right. \\ 2,12 \cdot \ln \left(1+0,11 \cdot \mathrm{f}_{\mathrm{ck}}\right) \text { for concretes on the range } \mathrm{C} 55-\mathrm{C} 90\end{array}\right.$

$\rho_{\mid}=\mathrm{A}_{s \mid} /\left(b_{w} \cdot d\right)$

$\sigma_{\mathrm{cp}}=\mathrm{N}_{\mathrm{sd}} / \mathrm{A}_{\mathrm{c}}$

With $k$ being a coefficient that depends on the ratio of longitudinal reinforcement that reaches the supports (for elements where $50 \%$ of the bottom reinforcement on single supported slabs does 

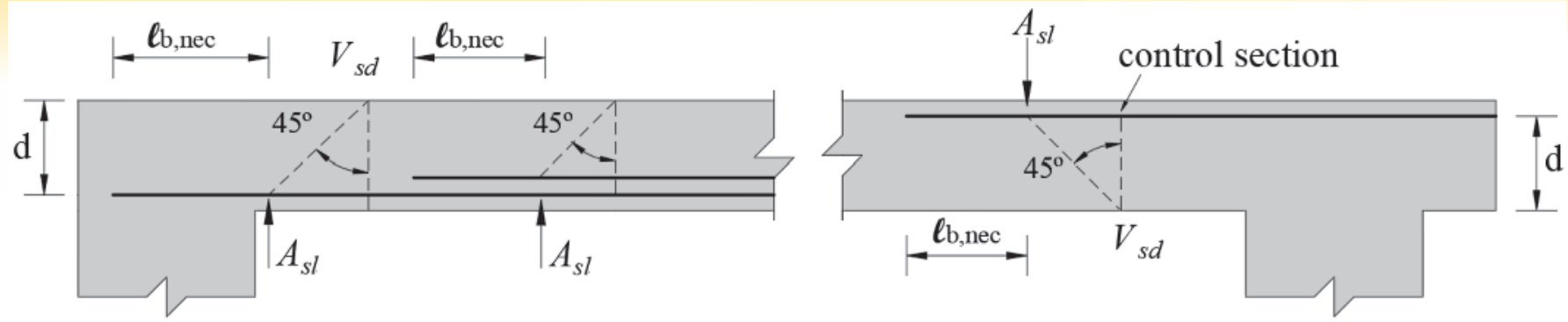

\section{Figure 2}

Required anchoring length (adapted from ABNT NBR 61 18:2014 [11])

not reach the support: $k=|1|$, and for the other cases: $k=|1,6-d| \geq 1$, with $d$ in meters). $\tau_{R d}$ is the design shear strength of concrete, $A_{s \mid}$ is the area of longitudinal reinforcement which extends to not less than $d+l_{b, \text { nec }}$ (defined in the item 9.4.2.5 of the Brazilian code) and illustrated in Figure $2, b_{w}$ is the effective width of the cross section along the effective depth $\mathrm{d}, \mathrm{N}_{\mathrm{Sd}}$ is the longitudinal force in the section due to the prestressing or thermal action (compression is considered positive).

For the comparison between the values predicted by the analytical models and the experimental values of shear strength, the following considerations were assumed: (i) the measured properties of the materials were used, (ii) all partial factors were considered equal to 1 and iii) the effective width was defined according to Figure 3. Figure $3 a$ represents the Dutch practice of defining the effective width [14] by horizontal spreading of the load from its center of application towards the support at $45^{\circ}$ angle. In Figure $3 \mathrm{~b}$ it is presented the French practice to define the effective width [15] with horizontal spreading of the load from the farthest face from the support and taking into account the width of the application area of the load. Figure $3 \mathrm{c}$ presents the model proposed in the Model Code 2010 [16].

In the current version of ABNT NBR 6118:2014 [11] guidelines for the definition of the effective width in shear strength are not available in the case of partially distributed loads in small areas close to supports. In the Brazilian design practice, especially in the case of bridge decks, the definition of a slab strip has been diffused from the vertical propagation of the shear force up to the mean plane of the slab at $45^{\circ}$, as recommended in ABNT NBR 6118: 1980 [17]. In this approach, the effective width in the shear strength is dependent on the relationship between the dimensions of the load application and the slab area [17] (Figure 4).

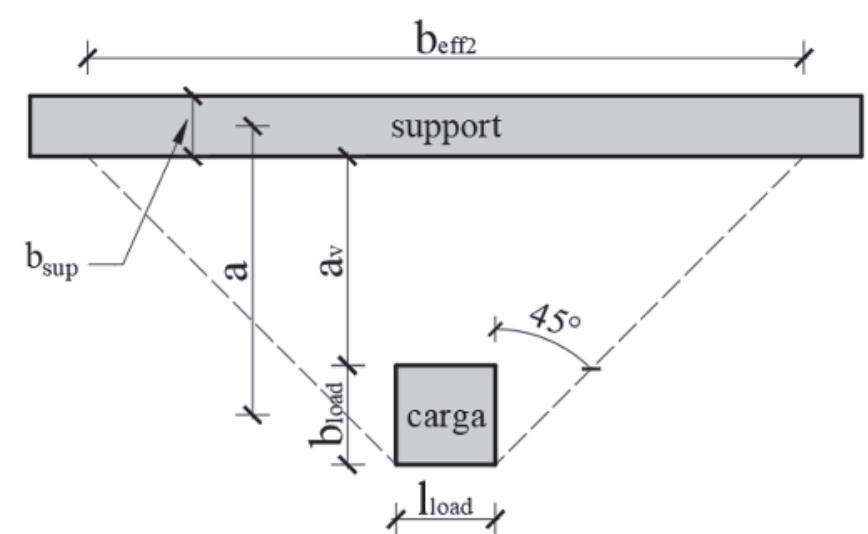

b)

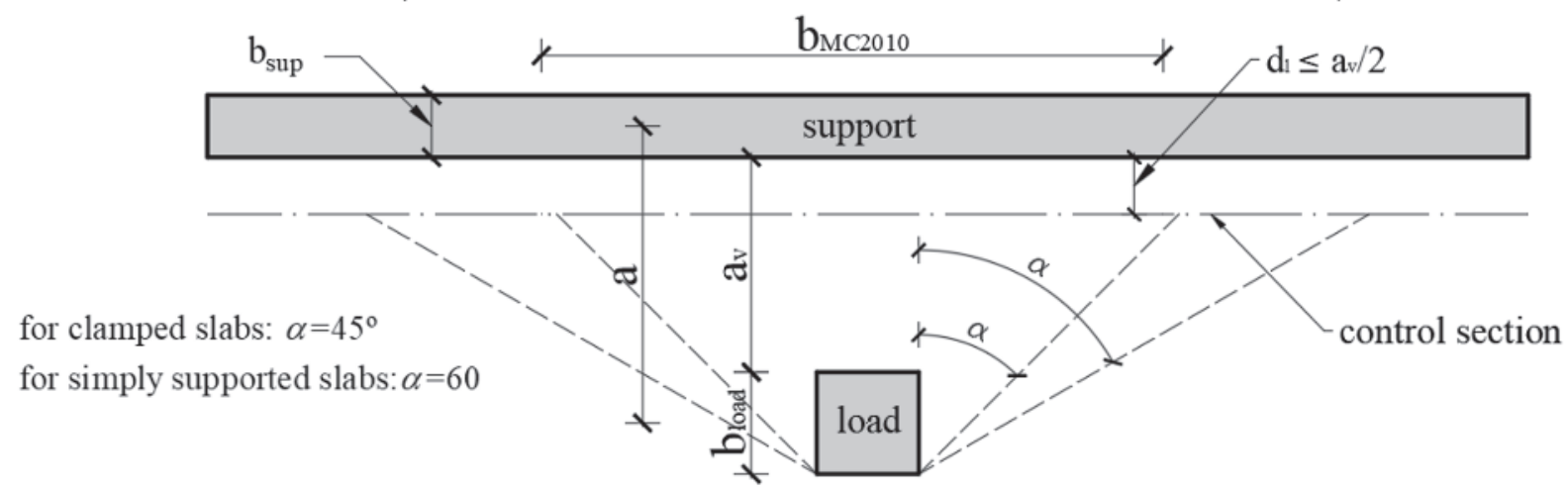

c)

\section{Figure 3}

Definition of the effective width in models of one-way shear force strength according to: a) Dutch method $\left(b_{\text {eff }}\right)$ [14], French method $\left(b_{\text {eff }}\right)$ [15] and c) Model Code 2010 [16] 


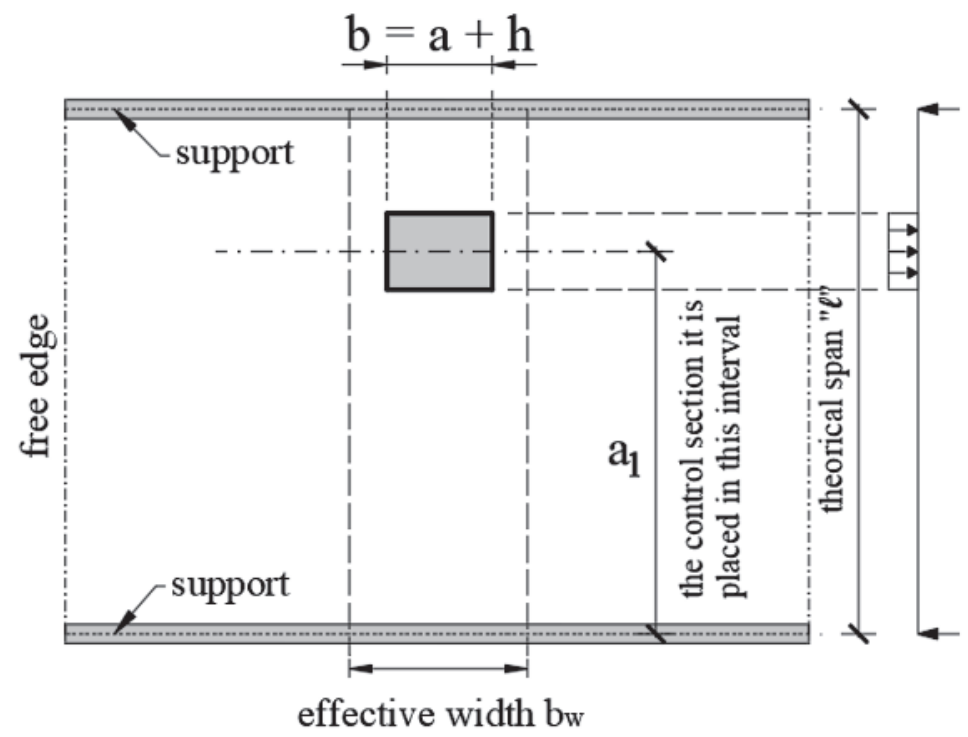

a)

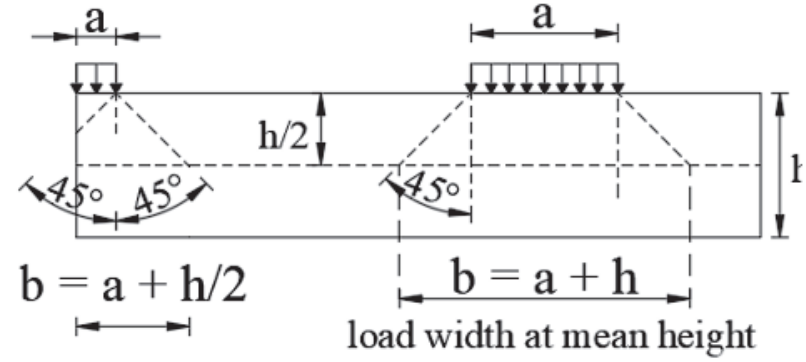

b)

\section{Figure 4}

Effective width definition according to ABNT NBR 6118:1980 [17]: a) top view and b) cross sectional view

\subsubsection{Aggregate interlock effect}

The aggregate interlock is directly influenced by the aggregate type and the compressive strength of concrete. In lightweight and high strength concretes, the cracks develop preferentially through the aggregate particles, which tends to produce cracked surfaces with less roughness. The effect of aggregate fracture is explicitly addressed in the Model Code 2010 [16] by means of the factor $k_{d g}$ in the definition of $k_{v}$ to level II approximation. In this code the aggregate fracture effect is taken into account assuming $d_{g}=0$ for concrete with a compressive strength exceeding $70 \mathrm{MPa}$. Figure 5a provides the shear strength as a function of compressive strength of concrete according to ABNT NBR 6118: 2014 [11], Eurocode 2 [18], Model Code 2010 [16] and the Simplified approach from ACI 318-14 [19] (adapted example from Yang et al. [20] with $\mathrm{d}=460 \mathrm{~mm}, \rho_{\mathrm{I}}=1,75 \%$ and $\left.\varepsilon_{\mathrm{x}}=0,00125\right)$.

Yang et al. [20] point out, however, that the formulation provided by the Model Code 2010 [16] inserts a discontinuity in the relationship between compressive strength of concrete and the shear strength (Figure 5a), which causes an abrupt reduction of shear strength $(>40 \%)$ when the compressive strength of concretes reaches $70 \mathrm{MPa}$. The effect of aggregate interlock is not explicitly addressed in other formulations such as Eurocode 2 [18], ACI 318-14 [19] and ABNT NBR 6118:2014 [11]. Therefore, the shear strength calculated on these models increases continuously with the concrete compressive strength, which is not consistent with experimental observations on elements with compressive strengths of concrete greater than 65 $\mathrm{MPa}$. As shown in Figure $5 \mathrm{a}$, in addition to not considering the reduction of shear strength in the case of high strength concrete (resulting from the aggregate interlock reduction), the
ABNT model NBR 6118:2014 [11] considers a ratio increase of shear resistance greater than other codes and manuals.

\subsubsection{Longitudinal reinforcement ratio effect}

Figure $5 b$ outlines the effect of the longitudinal reinforcement ratio on shear strength by different models. Since in this analysis the cross sectional stress state of the element was not evaluated, the Brazilian code was compared to the simplified calculation models of ACI 318: 2014 [19] (ACl-S) and Model Code 2010 [16] on level I approximation ( $\mathrm{MC}(\mathrm{I}))$. It can also be noted that, while the Brazilian and European codes consider the progressive increase of shear strength with the increase in the longitudinal reinforcement rate, the $\mathrm{ACl} 318-\mathrm{S}$ and $\mathrm{MC}(\mathrm{I})$, in a more conservative manner, does not consider possible resistance gains by improvement on dowel effect.

\subsubsection{Size effect}

Figure $5 c$ and Figure $5 d$ present the thickness effect (scale) of the elements in the prediction of shear strength of a slabs strip $\left(f_{c}=30 \mathrm{MPa}, \rho_{1}=1,75 \%\right.$ and $\left.b=1 \mathrm{~m}\right)$ by different models. It is observed that the simplified model of ACI 318: 2014 [19], by not incorporating parameters for the scale effect, leads to overestimated shear strength values in elements of high thicknesses. However, as in slabs the thicknesses are generally much lower than those of beams, the American model is still widely used. In the ABNT NBR 6118:2014 [11] and Eurocode 2 [18] models the scale effect is considered in the formulation by parameter "k", while in the Model Code 2010 (Level II approximation) [16] the scale effect is taken into account by the use of $\mathrm{k}_{\mathrm{v}(\mathrm{II})}$. 
It can be noted that, in the ABNT NBR 6118:2014 [11] code, the scale effect that reduces the design shear strength of concrete is no longer considered for thicknesses greater than $60 \mathrm{~cm}$, with a constant level from this value. In the case of Eurocode 2 [18] it can be observed that the scale effect is considered only for thicknesses greater than $20 \mathrm{~cm}$.

\subsubsection{Shear span to depth ratio effect $-(a / d)$}

The ratio a/d, where "a" is the distance face to face between load

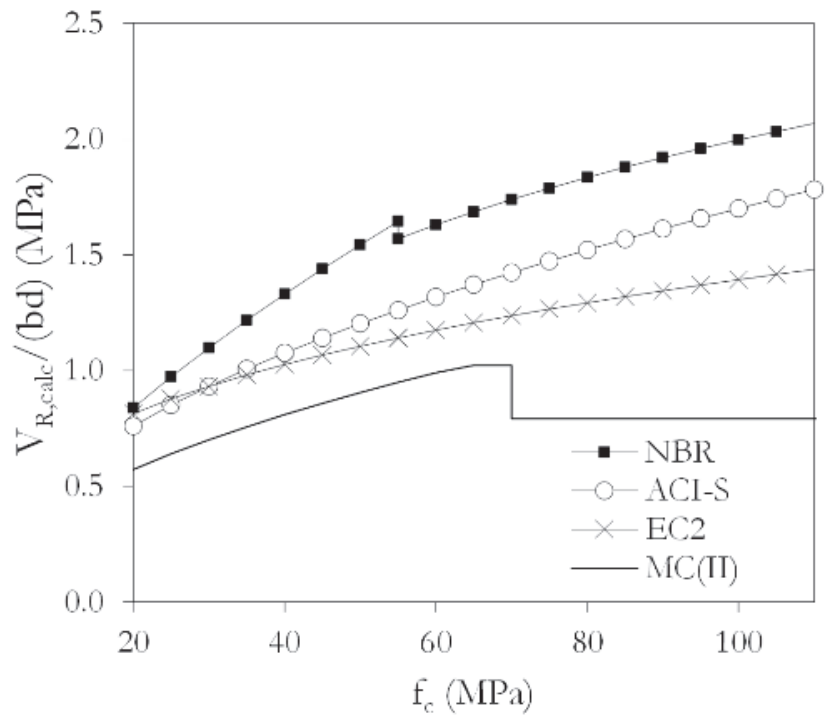

a)

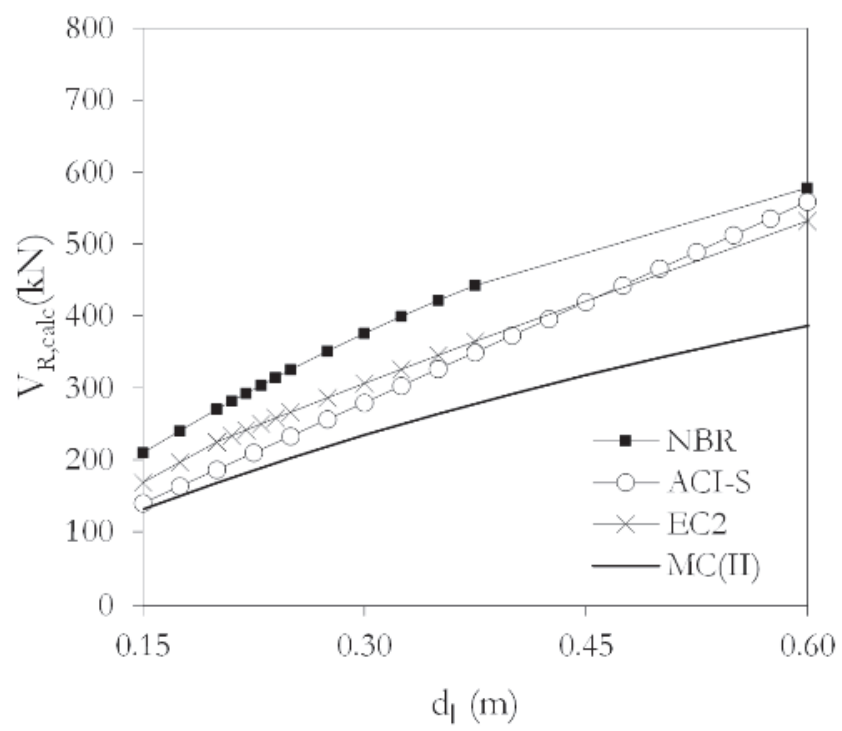

c) and support and "d" is the effective depth of longitudinal reinforcement, takes effect in the main mechanisms of shear transfer $\left(V_{c}, V_{a g}, V_{\text {dowel }}\right.$ and $\left.V_{\text {res }}\right)$ and in the arch effect [21,22]. Muttoni and Fernandez Ruiz [23] explain that four regimes govern shear failures according with the shear slenderness a/d (Figure 6): (i) for relations $a / d \leq 1$ the strength of the element is governed by yielding of flexural reinforcement, since the shear/bending cracks do not intercept the compression struts, (ii) for relations of approximately $1<\mathrm{a} / \mathrm{d}<2,5 \sim 3$

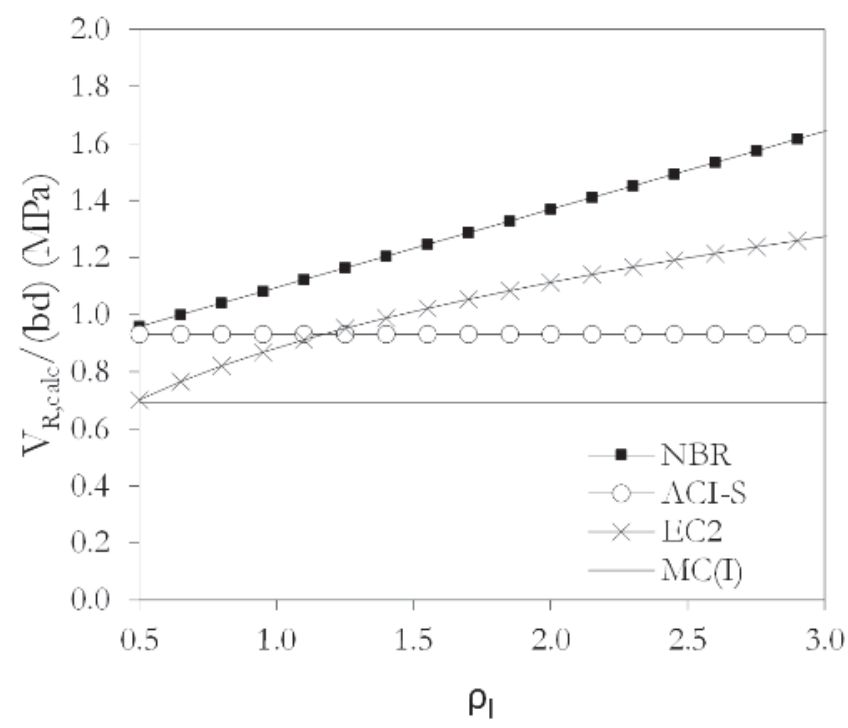

b)

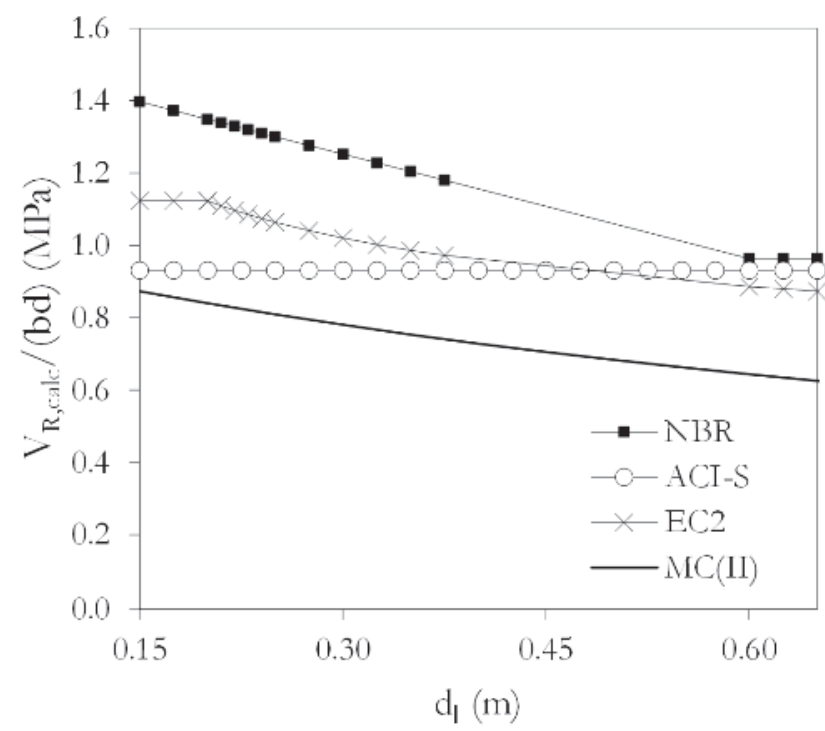

d)

\section{Figure 5}

Effect on shear force strength (according to the one-way approach to slabs) of parameters such as:

a) Concrete compressive strength, b) ratio of flexural reinforcement and c) and d) effective depth of the elements (scale effect) 


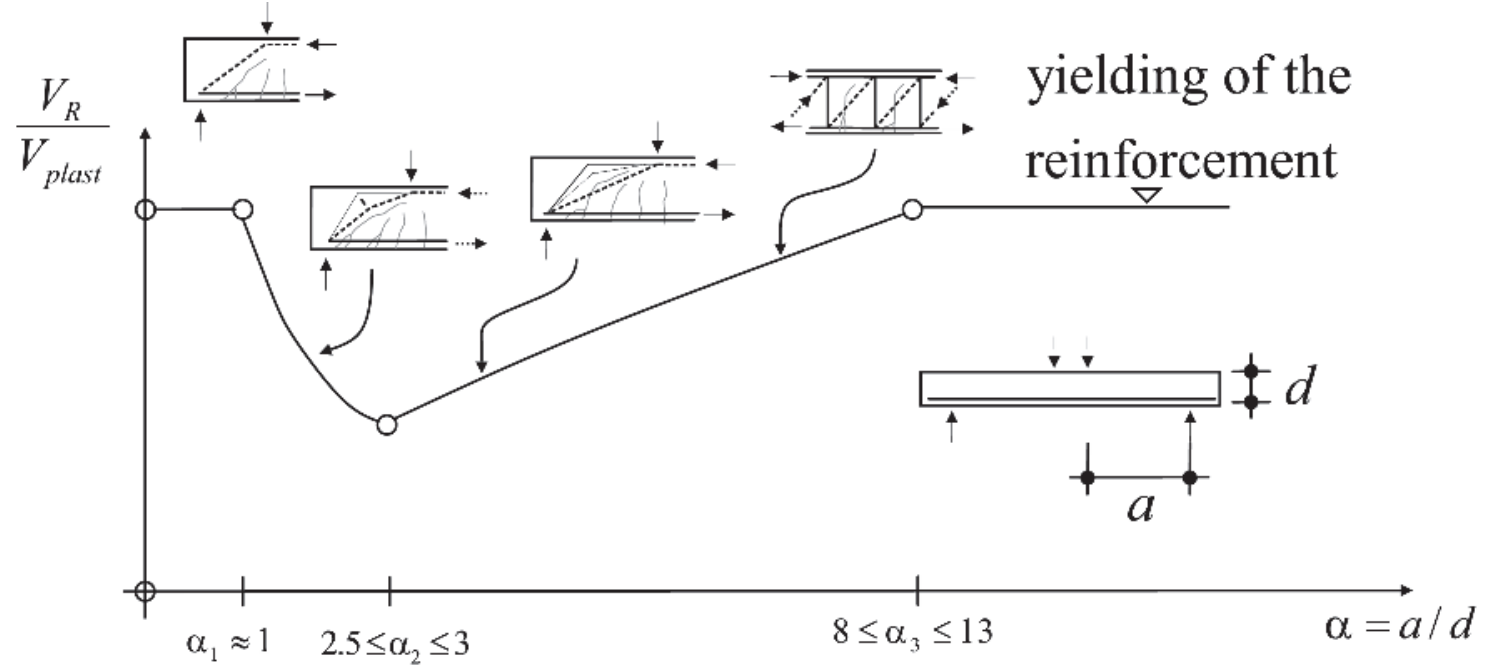

\section{Figure 6}

Influence of the shear span to depth ratio $a / d$ in the shear force strength (adapted from Muttoni and Fernandez Ruiz [23])

the arching action is dominant, since the shear cracking can intercept or not the compression strut, (iii) for relations $2,5 \sim 3,0<\mathrm{a} / \mathrm{d}<8 \sim 13$ the governing failure mode is aggregate interlock and (iv) for very slender elements a/d > 8 13 the governing failure mode is again the yielding of flexural reinforcement. In Figure $6, V_{r}$ is the shear strength and $V_{\text {plast }}$ is the plastic strength.

The item 17.4.1.2.1 from ABNT NBR 6118:2014 [11] considers the possibility of shear force reduction in the case of concentrated loads close to supports in beams, reflecting the knowledge about the direct transfer of part of the load through mechanisms of compression struts and arching effect until relations $\mathrm{a} / \mathrm{d}<2,5$, being "a" the distance between axes of load and support and "d" the effective depth. In the Brazilian code [11] the shear force reduction is allowed for loads placed in distances a $\leq 2 \mathrm{~d}$ from the theoretical axis of the support by multiplying the design shear force by the relation $\mathrm{a} / 2 \mathrm{~d}$. However, the Brazilian code does not present provisions in the case of slabs, which are already accepted in the European code [18] and in the Model Code 2010 [16]. In the European code [18] the shear force reduction is allowed for loads applied at distances $0,5 \leq$ $a_{v} \leq 2 d$ from the edge of a support (or centre of bearings where flexible bearings are used), being $a_{v}$ the distance between edge of loads and supports, through multiplication of $V_{E d}$ by:

$\beta_{E C}=a_{V} / 2 d,\left(0,25 \leq \beta_{E C} \leq 1\right)$

In the case of the Model Code 2010 the same procedure is allowed, but with $0,5 \leq \beta_{\mathrm{MC}} \leq 1$. In the posterior developments, the effect of the consideration of the European coefficient $\beta_{E C}$ was evaluated in the level of precision of the Brazilian code.

\subsection{Punching capacity model}

The punching capacity model for slabs is presented in item
19.5.1 of ABNT NBR 6118: 2014 [11] and deals with the verification of shear strength on two or more critical surfaces defined around concentrated or distributed loads in small areas (like wheel loads). In the first critical surface (contour $C$ of Figure $7 a$ ) the shear stress $\tau_{S d}$ should be evaluated indirectly by checking the diagonal compression strength of the concrete $\tau_{\mathrm{Rd} 2}$. On the second critical surface (contour $C^{\prime}$ of Figure $7 a$ ), distant $2 \mathrm{~d}$ from the edges of the column or partially distributed load, the punching capacity is checked by diagonal tensile strength of concrete $\tau_{\mathrm{Rd} 1}$. This verification may be done by calculating a shear stress in the contour C'.

$\tau_{S d} \leq \tau_{R d 2}=0,27 \cdot \alpha_{V} \cdot f_{c d}($ perimeter $C)$

$\alpha_{v}=\left(1-f_{c k} / 250\right)$, with $f_{c k}$ in MPa

$\tau_{S d} \leq \tau_{R d 1}=0,18 / \gamma_{c} \cdot(1+\sqrt{20 / d}) \cdot\left(100 \cdot \rho \cdot f_{c k}\right)^{1 / 3}+0,10 \cdot \sigma_{c p}$ (perimeter $C^{\prime}$ )

$\left.\rho=\sqrt{\rho_{1} \cdot \rho_{\mathrm{t}}}\right)$

$d=\left(d_{1}+d_{t}\right)$

Where $d$ is the effective depth of the slab along the critical perimeter considered (in centimeters), $\rho$ is the average ratio of bonded reinforcement (unbonded reinforcement should not be considered according to ABNT NBR 6118:2014 [11]), $\rho_{\text {, }}$ and $\rho_{\mathrm{t}}$ are the flexural reinforcement ratio at longitudinal and transverse direction. In the case of Figure $7 \mathrm{~b}$ it is pointed out that it is required to reduce the perimeter considered due to the load placed near the edge. Similar procedure should be used in situations where the load is not on the edge, but is close to the edge.

The definition of the shear stress on critical perimeter depends mainly on the position of the loaded area in relation to the slab and the moment effect of the load in the slab. On this, it is pos- 
sible to deal in a similar way with the case of partially distributed loads close to supports and the case of internal columns with moment effect provided in ABNT NBR 6118: 2014 [11]. Thus, the shear stress due to loading in the critical perimeter is:

$\tau_{S d}=\frac{F_{S d}}{u \cdot d}+\frac{K \cdot M_{S d}}{W_{p} \cdot d}$

Where $\mathrm{M}_{\mathrm{Sd}}=\mathrm{F}_{\mathrm{Sd}} \cdot \mathrm{e}_{\mathrm{F}}$, with $\mathrm{e}_{\mathrm{F}}$ being a term that can be approximately determined by the eccentricity between the center of the loaded area and the center of gravity of the internal area of the critical perimeter. For a more accurate estimate of $e_{F}$ a non-linear analysis should be performed [13]. The equation (2.14) can then be rewritten as:

$\tau_{S d}=\frac{F_{S d}}{u \cdot d} \cdot\left(1+\frac{K \cdot e_{F} \cdot u}{W_{p}}\right)$

Where the term $1+K \cdot e_{F} \cdot u / W_{p}$ is equal to parameter $\beta_{\text {eccentricity }}$ defined on item 6.4.3 of Eurocode 2 [18] (associated with the moment effect of the load in relation to the critical perimeter and not to $\left.a_{v} / 2 d\right)$. In both formulations $K$ is a coefficient dependent on the ratio of the dimensions $C_{1}$ and $C_{2}$ of column or load, its value being the function of the unbalanced moment transmitted by irregular shear stress and by moment and torsion (Figure 8a). In this formulation $\mathrm{W}_{\mathrm{p}}$ corresponds to modulus of plastic resistance at the critical perimeter and is a function of the shear distribution as shown in Figure 8b.

For a partially distributed load in a rectangular area the modulus of plastic resistance $\mathrm{W}_{\mathrm{p}}$ is determined by:

$W_{p}=\frac{c_{1}^{2}}{2}+c_{1} \cdot c_{2}+4 \cdot c_{2} \cdot d+16 \cdot d^{2}+2 \cdot \pi \cdot d \cdot c_{1}$

However, in the case of partially distributed loads near supports, the original distance $2 d$ is replaced by the reduced distance $a_{v}$ [13], which represents the distance between faces of the load and the support, resulting in the relation: $w_{p}=\frac{c_{1}^{2}}{2}+c_{1} \cdot C_{2}+2 \cdot a_{v} \cdot c_{2}+4 \cdot a_{v}^{2}+\pi \cdot a_{v} \cdot c_{1}$

It can be observed that the only difference between the punching models of the Brazilian and European standards is the consideration of minimum shear strength in the latter, with the Brazilian approach being more conservative in this sense. The comparison between the results measured experimentally and calculated by the punching capacity model of ABNT NBR 6118: 2014 [11] considers the following simplifications: (i) the properties of the measured materials are used, (ii) all partial safety factors are equal to 1 , (iii) the minimum perimeter length was used and (iv) the self-weight was not taken into account.

\section{Database}

The database used was presented by Lantsoght et al. [13], which include the works of Reissen and Hegger [9,10], Regan [24], Sherwood et al. [25], Vaz Rodrigues et al. [26], Jäguer [27], Jäguer [28,29], Graf [30], Richard and Kluge [31], Diaz de Cossio et al. [32], Rajagopalan and Fergusson [33], Aster and Koch [34], Heger and McGrath [35], Cullington et al. [36], Coin and Thonier [37], Olonisakin and Alexander [38] and Rombach and Latte $[39,40]$.

This database brings together a total of 215 experiment results from literature. However, as pointed out by Lantsoght et al. [13], only 22 experiments on slabs with loads close to the support $\left(b_{\text {slab }}>b_{\text {eff } 2}\right.$ and $a / d<2,5$ - case of major interest in bridge slabs) are available in this database, most of which were performed in experiments of reduced thickness $(\mathrm{h} \leq 150 \mathrm{~mm}$ ). Lantsoght et al. [13] explains that bridge decks on integral bridges usually have thickness $h \geq 300 \mathrm{~mm}$, so that most of the results available in the literature are influenced by the scale effect of the experiments. The scale effect refers to the experimental

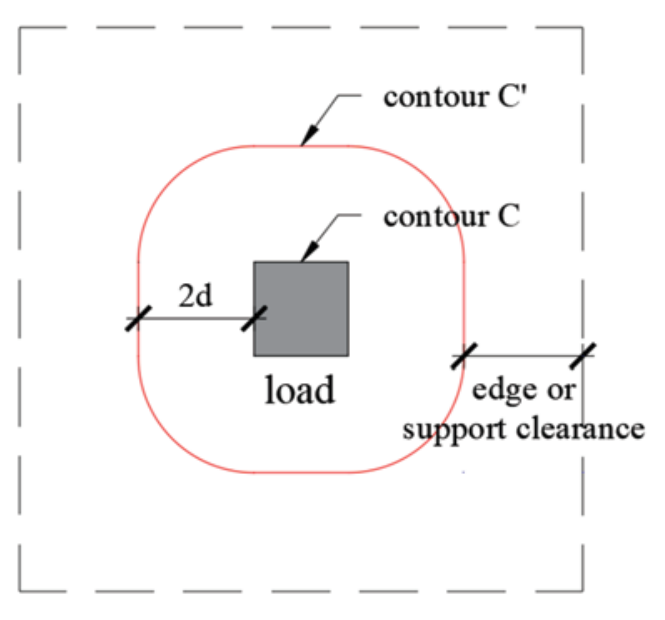

a)

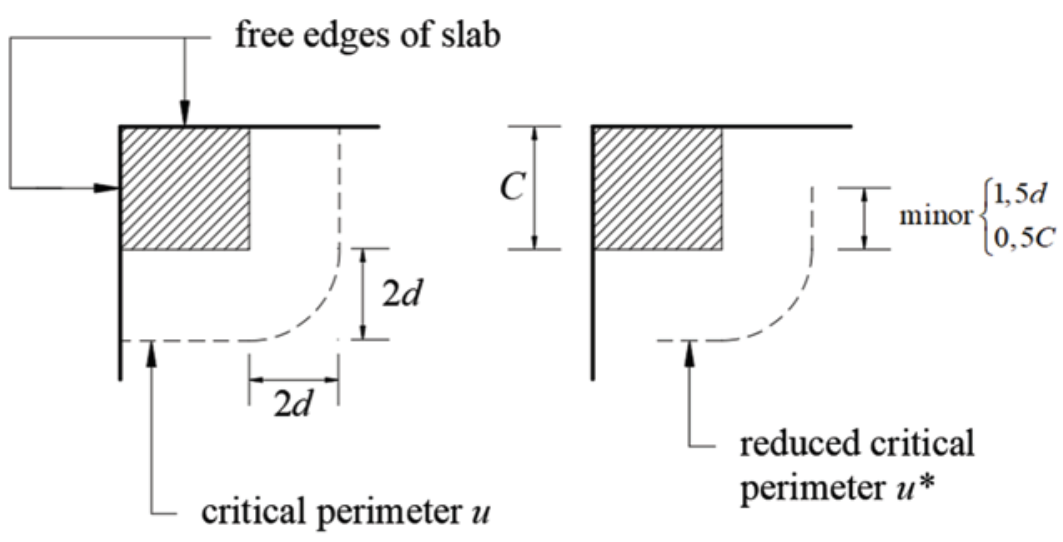

b)

Figure 7

a) Definition of critical perimeter in regions distant from free edges and b) regions close to free edges (adapted from ABNT NBR 6118: 2014 [11]) 
observation of lower resistant shear stresses in thicker elements [41].

Lantsoght et al. [13] also comments that many of the experiments reported in the literature present a combination of failure modes involving one-way shear and/or punching with flexure. In order to eliminate the experiments that may have failed in flexure these were evaluated through the simplified rectangular stress diagram for the active bending moment [13]. In this analysis, the lever arm $z$ was assumed as $0,9 \cdot d_{1}$ and the height of the rectangular stress diagram was adopted as $0,2 \cdot d_{1}$. Based on these analyses the database was reduced to a total of 118 experiments, of which 87 were reported to fail as wide beams (WB) and 21 experiments reported failing by punching $(P)$. As the experiments of Graf [30] presented loads very close to the support, which resulted in distances $a_{v} \leq 0$ these results were discarded in later analyses.

\section{Results and discussions}

\subsection{One-way shear model}

\subsubsection{Effect of the effective width model and coefficient $\beta_{\mathrm{EC}}$}

Figure 9 presents the graphical results of the application of the prediction model of shear strength in slabs and linear elements with $b_{w} \geq 5 d$ recommended by ABNT NBR 6118:2014 [11] to the

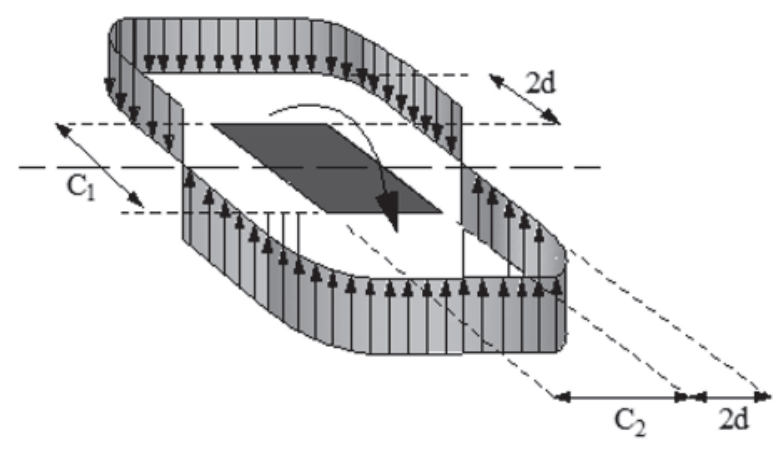

a)

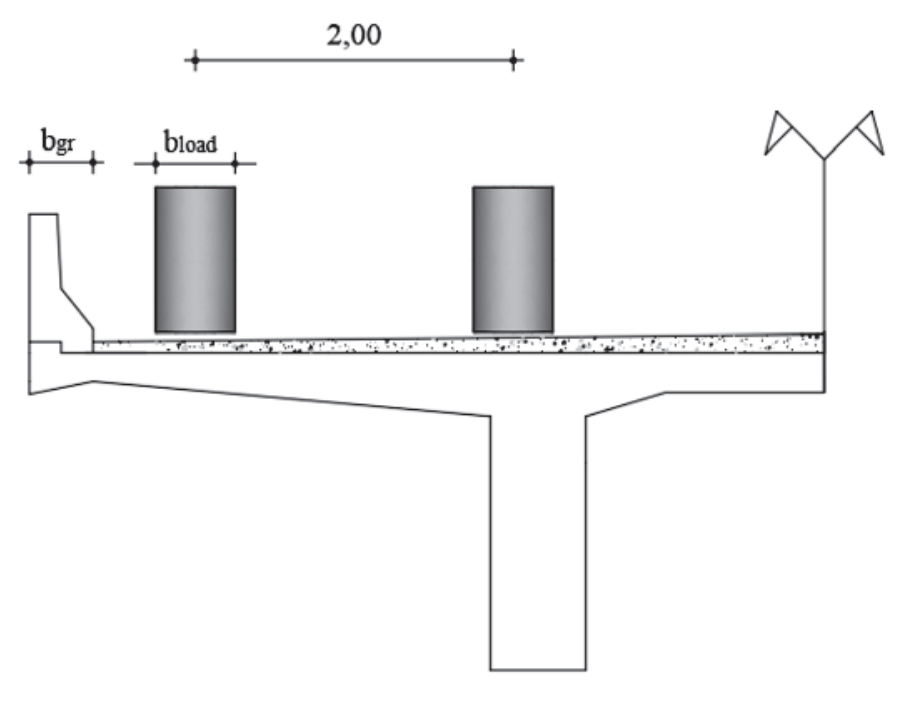

b)

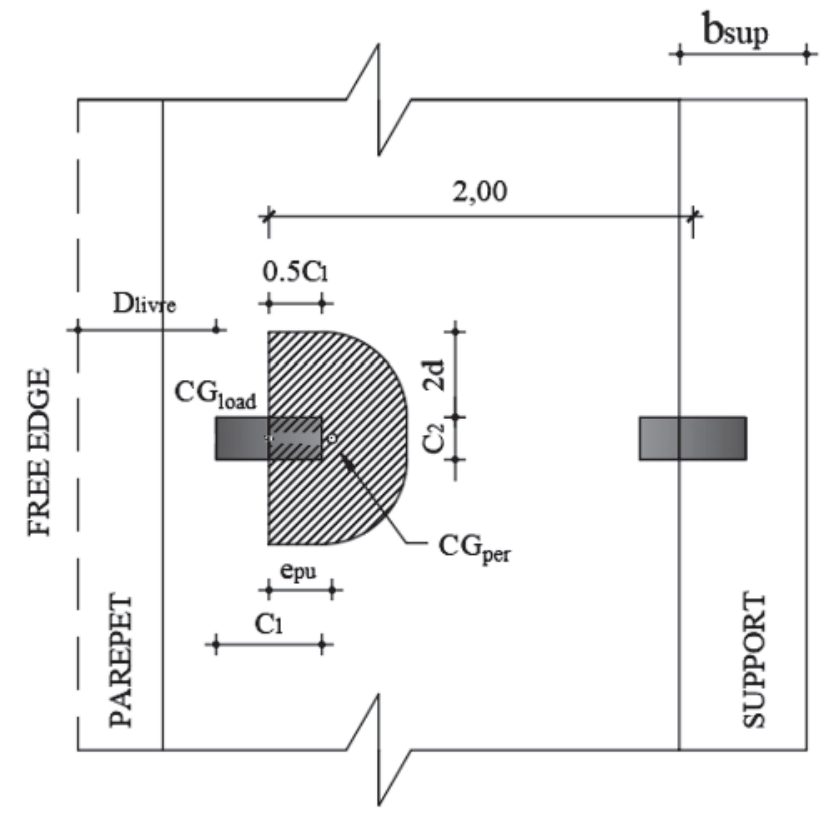

c)

\section{Figure 8}

a) Distribution of shear force due to unbalanced moment in a slab-column connection (adapted from Eurocode 2 [18]), b) cross section of a cantilever slab bridge and c) example of eccentricity determination between the loaded area and the punching perimeter (top view) 
database used in this paper. In Figure 9a and Figure 9b the Dutch method was used to define the effective width $\left(b_{\text {eff }}\right)$. In Figure 9c and Figure $9 d$ the French method was considered to define the effective width $\left(b_{\text {eff }}\right)$. Figure 9 also present the results considering the factor $\beta_{\mathrm{EC}}$ (Figure $9 \mathrm{~b}$ and Figure $9 \mathrm{~d}$ ) or not (Figure 9a and Figure $9 \mathrm{c}$ ) for the reduction of the design shear force in the case of loads distributed in small areas close to supports. Table 1 present the scatter measurements between the experimental and calculated values of shear strength $\left(\mathrm{V}_{\text {exp }} / \mathrm{V}_{\mathrm{NBR}}\right.$ or $\left.\mathrm{V}_{\text {exp,red }} / \mathrm{V}_{\mathrm{NBR}}\right)$. From Figure 9 it is observed that the consideration of the $\beta_{\mathrm{EC}} \mathrm{im}-$ proved the correlation coefficient $\mathrm{R}^{2}$ of the linear regression between the experimental and calculated values from 0,499 to 0,628 with the Dutch approach and from 0,666 to 0,770 with the French approach to defining the effective width. Among the different approaches to defining the effective width, it was observed that the French approach $b_{\text {eff2 }}$ provided better correlations between

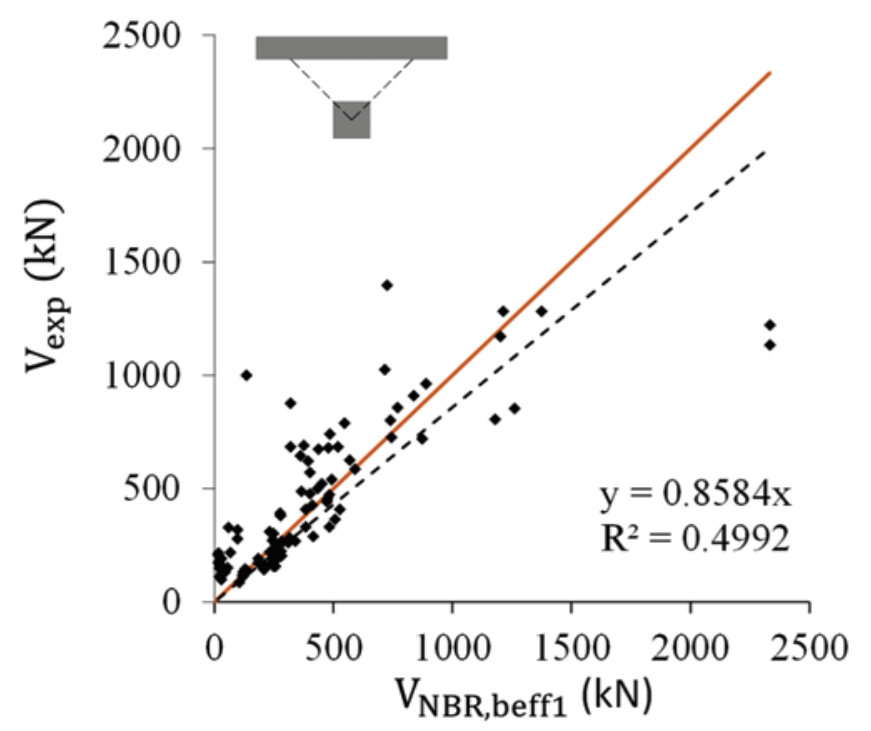

a)

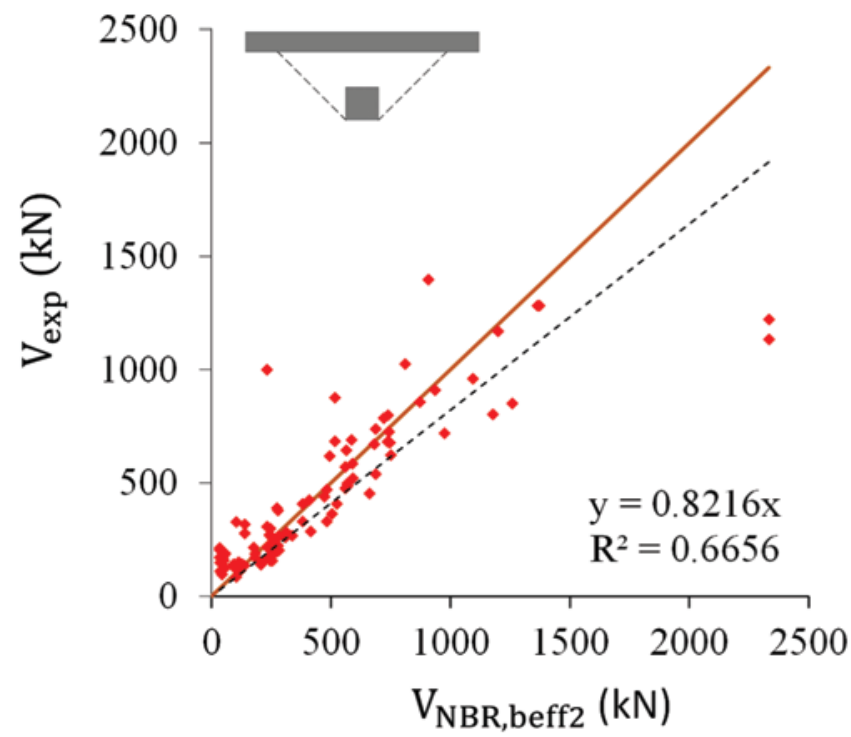

c)

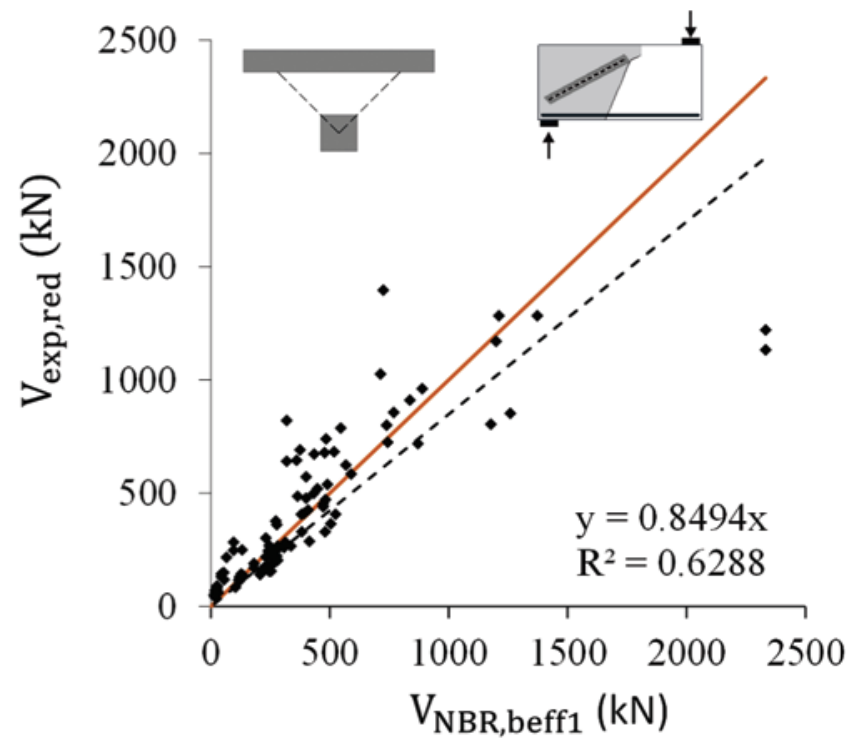

b)

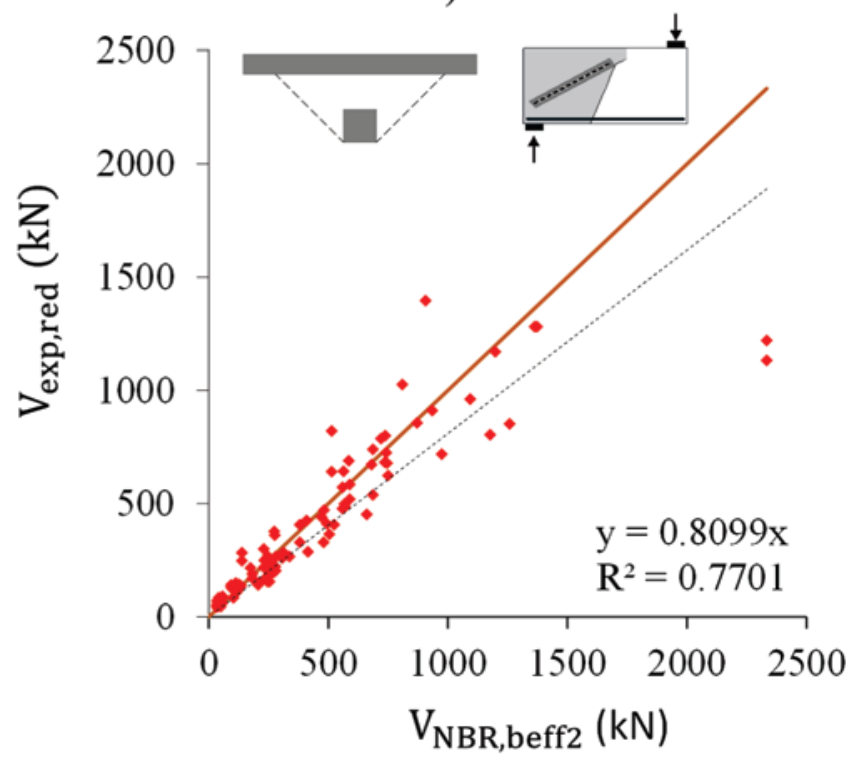

d)

Figure 9

Comparison between experimental and predicted values for shear force strength according to ABNT NBR $6118: 2014$ [11] a) without $\beta_{\mathrm{EC}}$ and with $b_{\text {eff }}$, b) With $\beta_{\mathrm{EC}}$ and $b_{\text {eff }}, c$ ) Without $\beta_{\mathrm{EC}}$ and with $b_{\text {eff2 }}$ and d) With $\beta_{\mathrm{EC}}$ and with $\mathrm{b}_{\text {eff2 }}$ 
Table 1

Comparison of results using ABNT NBR 6118 [11]

\begin{tabular}{ccccc} 
& $\mathbf{V}_{\text {exp }} / \mathbf{V}_{\text {NBR,beff1 }}$ & $\mathbf{V}_{\text {exp,red }} / \mathbf{V}_{\text {NBR,beff1 }}$ & $\mathbf{V}_{\text {exp }} / \mathbf{V}_{\text {NBR,beft2 }}$ & $\mathbf{V}_{\text {exp,red }} / \mathbf{V}_{\text {NBR,beff2 }}$ \\
\hline$\mu$ & 2,00 & 1,37 & 1,34 & 1,02 \\
$\sigma$ & 2,50 & 0,79 & 1,06 & 0,30 \\
$v$ & $124,5 \%$ & $57,7 \%$ & $78,9 \%$ & $29,7 \%$ \\
\hline
\end{tabular}

$\mu=$ average value; $\sigma=$ standard deviation; $v=$ coefficient of variation

experimental and calculated values $\left(R^{2}=0,77\right)$ compared to the Dutch approach $b_{\text {eff } 1}\left(R^{2}=0,63\right)$. However, although the level of correlation has improved when considering $b_{\text {eff2 }}$ and the coefficient $\beta_{\mathrm{EC}}$, the percentage of model failures $\left(\mathrm{V}_{\text {exp.red }}<\mathrm{V}_{\mathrm{NBR}}\right)$ with these procedures resulted quite high ( $58 \%$ in Figure $9 \mathrm{~d}$ ), illustrated by the greater number of points to the right of the line at $45^{\circ}$ in Figure $9 b$

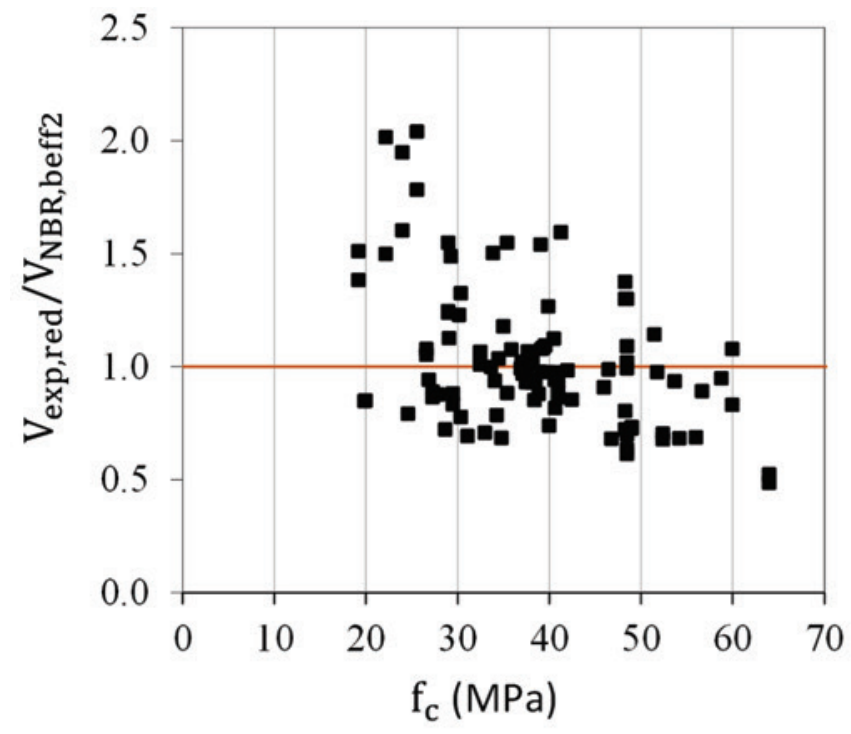

a)

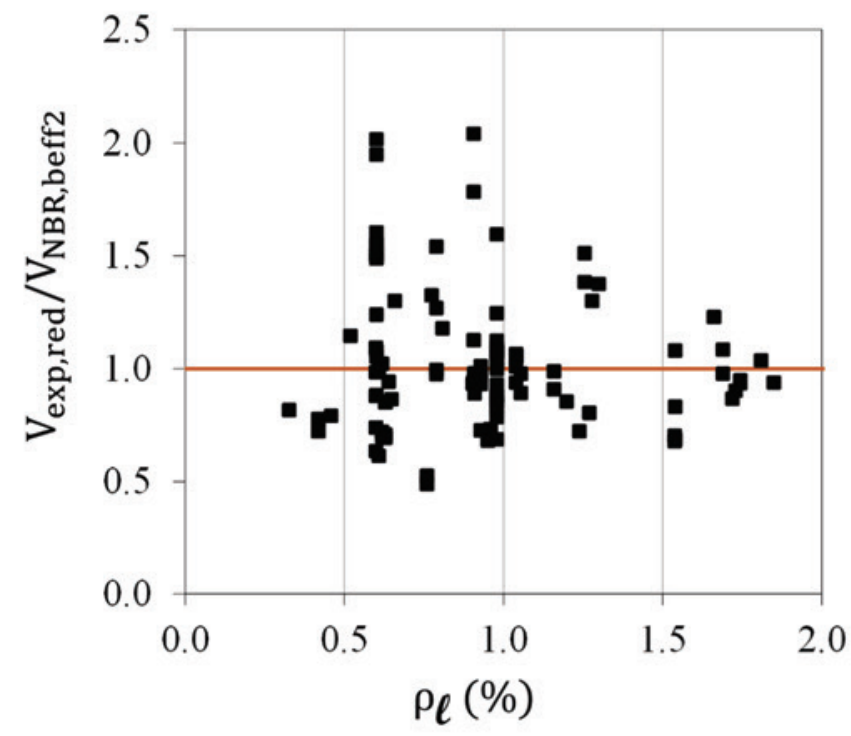

c) and Figure 9d and also by the angular coefficient of the linear regression equation farthest from the unitary in these cases. Therefore, it can be stated that the lack of consideration of the coefficient $\beta_{\mathrm{EC}}$ and the use of the Dutch approach $\left(b_{\text {eff } 1}\right)$ to define the effective width tends to be more conservative, although it has also resulted in a high percentage of unsafe predictions $(43 \%)$.

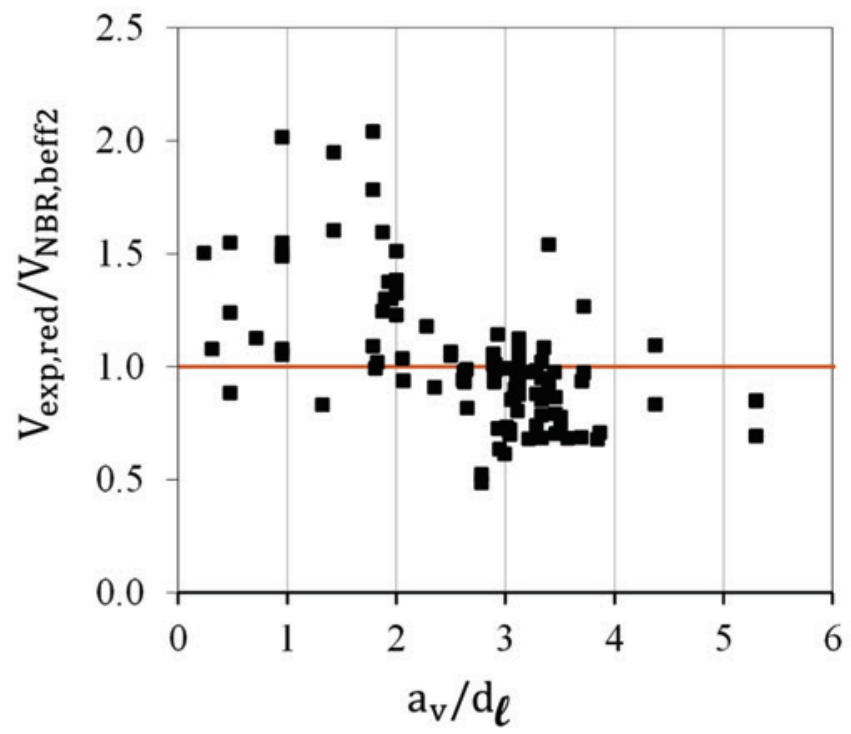

b)

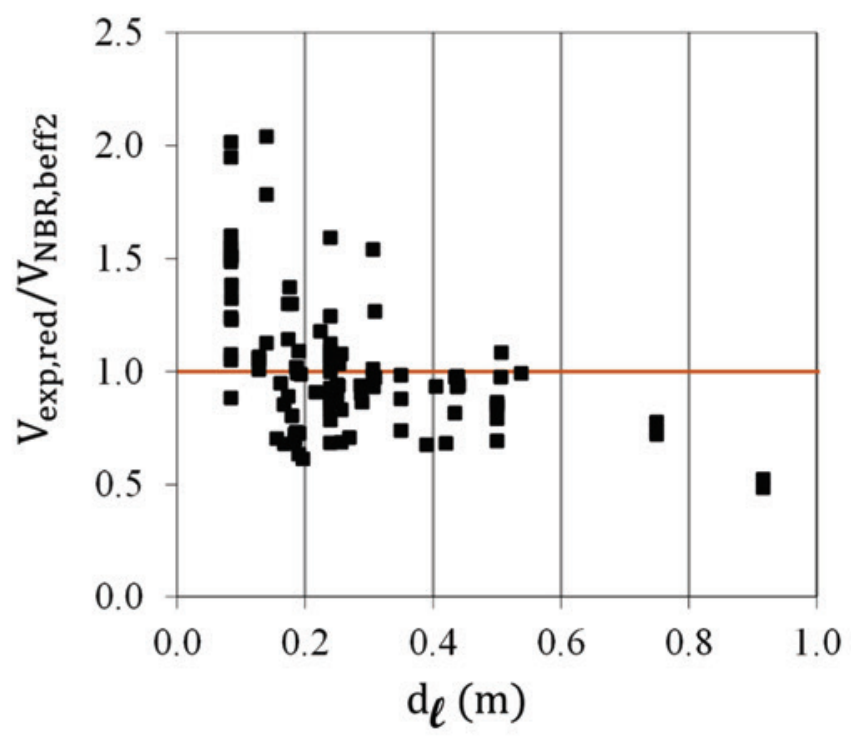

d)

\section{Figure 10}

$V_{\text {exp }} / V_{\text {cal }}$ ratio provided by ABNT NBR 61 18:2014 according to: a) compressive strength of concrete $f_{c^{\prime}}$ b) ratio $a_{v} / d_{1}, c$ ) ratio of flexural reinforcement $\rho_{1}$ and $d$ ) effective depth of longitudinal reinforcement $d_{1}$ 
From Table 1 it can be observed numerically that the mean value $(\mu)$ of ratio $V_{\text {exp }} / V_{\text {NBR }}$ using the Dutch approach to defining the effective width $\left(b_{\text {eff } 1}\right)$ improved from 2,00 to 1,37 considering the reduction of the design shear force $\left(\beta_{\mathrm{EC}}\right)$, in the case of loads distributed in small areas near the support, with a significant reduction in the coefficient of variation (v), that reduced from $124,5 \%$ to $57,7 \%$. This very high scatter of values was significantly reduced with the French approach to defining the effective width $\left(b_{\text {eff } 2}\right)$, with the average value of the relation $V_{\text {exp,red }} / V_{\text {NBR,beff } 2}$ assuming an average value of 1,02 and with the coefficient of variation of approximately $30 \%$.

\subsubsection{Effect of specific parameters}

Due to the complexity involved in the shear strength and the shear transfer mechanisms mobilized in reinforced concrete elements, it is common to analyze the accuracy of the calculation models according to specific parameters. Since the best level of accuracy obtained with ABNT NBR 6118: 2014 [11] was obtained with the effective width defined according to the French method $\left(b_{\text {eff }}\right)$ and using the coefficient of reduction of the design shear force $\beta_{E C}$, these considerations were used in the subsequent analyses presented in Figure 10.

In Figure 10a it is observed that the procedure of the Brazilian code tends to be more conservative for the smaller ranges of concrete resistances, with the results $V_{\text {exp,red }} / V_{\text {NBR }}$ assuming $\mu=1,11$ and $\mathrm{v}=28 \%$ in the range $\mathrm{f}_{\mathrm{c}}<40 \mathrm{MPa}$ and $\mu=0,89$ and $v=26 \%$ in the range $f_{c}>40 M P a$. Figure $10 \mathrm{~b}$ shows a slight tendency towards greater conservatism of the Brazilian code for lower relations $a_{v} / d_{1}$ and unsafe predictions to shear span to depth ratios $a_{v} / d_{1}>3$, indicating that perhaps the punching models fit better in the case of loads further away from the support. In Figure $10 \mathrm{c}$ it is observed that a high-

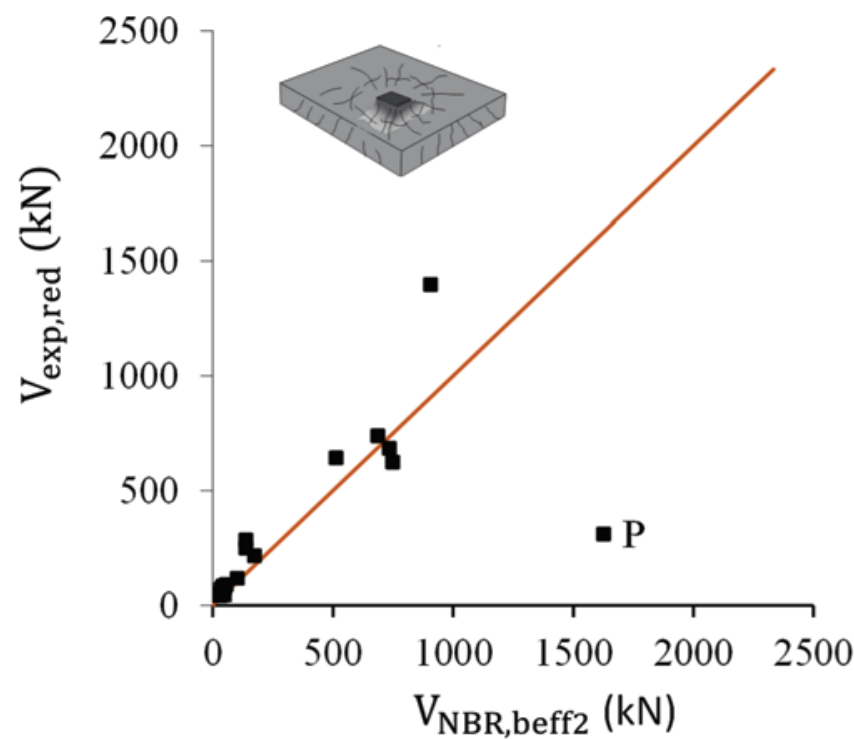

a) er level of scatter is reached for lower ratios of flexure reinforcement, with the ratio $V_{\text {exp,red }} / V_{\text {NBR,beff } 2}$ assuming $\mu=1,04$ and $\nu=30 \%$ to $\rho_{1}<1,4 \%$ and $\mu=0,91$ and $v=17,5 \%$ to $\rho_{1}>1,4 \%$. In Figure $10 \mathrm{~d}$ it is observed that the highest level of scatter of the results is associated with elements with a lower effective height, indicating a strong influence of scale effect on the results.

\subsubsection{Failure mode}

In these analyses the experiments that presented intermediate failure mode between punching $(P)$ and wide beam $(\mathrm{WB})$ were excluded, as well as experiments without failure mode described in the references. The Figure 11a shows that the application of the oneway slab model with the definition of an effective width fits well in the case of punching failures near the supports, but this result may have been influenced by the reduced number of experiments failing by punching. In the analysis of the elements that failed by punching the ratio $V_{\text {exp,red }} / V_{N B R, \text { befi2 }}$ assumed mean value $\mu=1,42$ and coefficient of variation $v=26,57 \%$. In Figure $11 \mathrm{~b}$, with the one-way approach applied to experiments failing as wide beams (WB), a large number of experiments with unsafe predictions were observed. In this case the ratio $V_{\text {exp, red }} / V_{\text {NBR,beff2 }}$ resulted in $\mu=0,92$ and $v=20,29 \%$.

\subsubsection{Load position}

Figure 12 presents the level of precision of the results according to the model of definition of the effective width combined with the load position: load close to continuous support (CS) and influenced by the negative moment at support, load close to simple support (SS) and, loads close to support of cantilever slabs (CT), which present great influence of the flexural cracks in the shear strength.

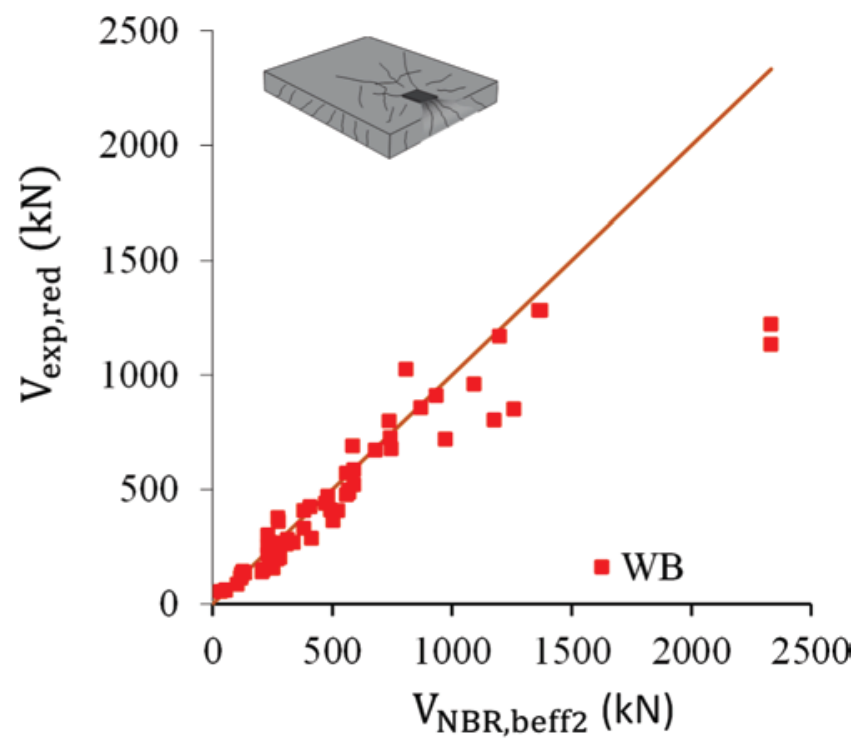

b)

\section{Figure 11}

Evaluation of the one-way model of shear force strength by ABNT NBR 61 18:2014 according to the failure mode of experiments: a) Punching (P), b) Wide Beam (WB) 


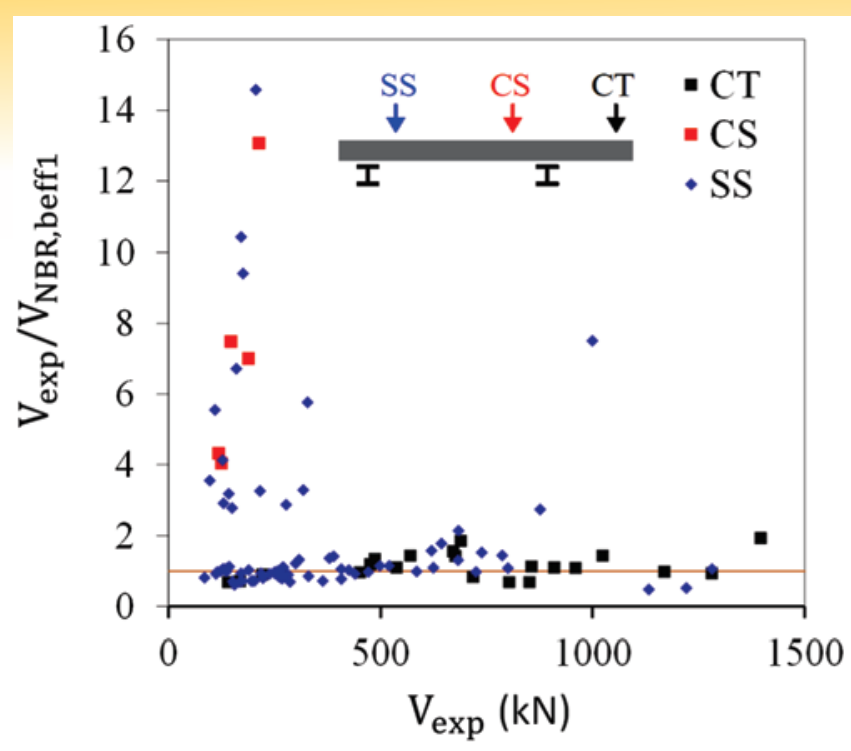

a)

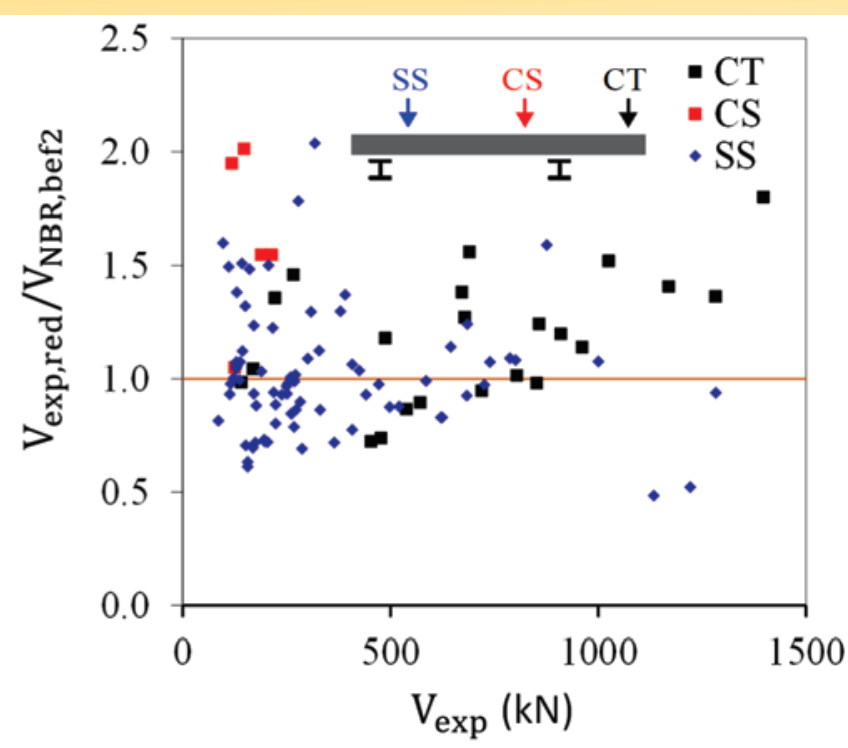

b)

Figure 12

Effect of loading typology in the case of: a) No consideration of factor $\beta_{\mathrm{EC}}$ and with $b_{\text {eff }}$ and b) With the factor $\beta_{\mathrm{EC}}$ and $\mathrm{b}_{\text {efi2 }}$

Figure 12a illustrates the high scatter of results not considering the coefficient $\beta_{\mathrm{EC}}$ to reduce the design shear force (for loads close to the support) and using the Dutch model of definition of the effective width $\left(b_{\text {eff }}\right)$, with very conservative predictions of shear strengths in some cases. The Figure $12 \mathrm{~b}$ shows a lower scatter predictions compared to Figure 12a, allowing a clearer identification of the influence of the load position on the accuracy level of the model. In Figure $12 \mathrm{a}$ and Figure $12 \mathrm{~b}$ it was observed that the formulation present a lower scatter in the case of cantilever slabs (CT), with the ratio $V_{\text {exp,red }} / V_{\text {NBR,beff } 2}$ assuming $\mu=0,92$ and $v=32,04 \%$, but with a high number of unsafe predictions in the model. A large number of unsafe predictions was also observed in the case of loads close to simple support ( $\mu=1,02$ and $v=27,44 \%$ ). In the case of loads near continuous supports (CS) unsafe predictions were not observed, although the level of precision of the results, which presented ratio $V_{\text {exp,red }} / V_{N B R, \text { beff2 }}$ with $\mu=1,62$ and $v=23,82 \%$, is questionable.

\subsection{Two-way approach (punching capacity model)}

\subsubsection{Force reduction close to the support by $\beta_{\mathrm{EC}}$}

Figure 13 presents the effect of to take into account the coefficient

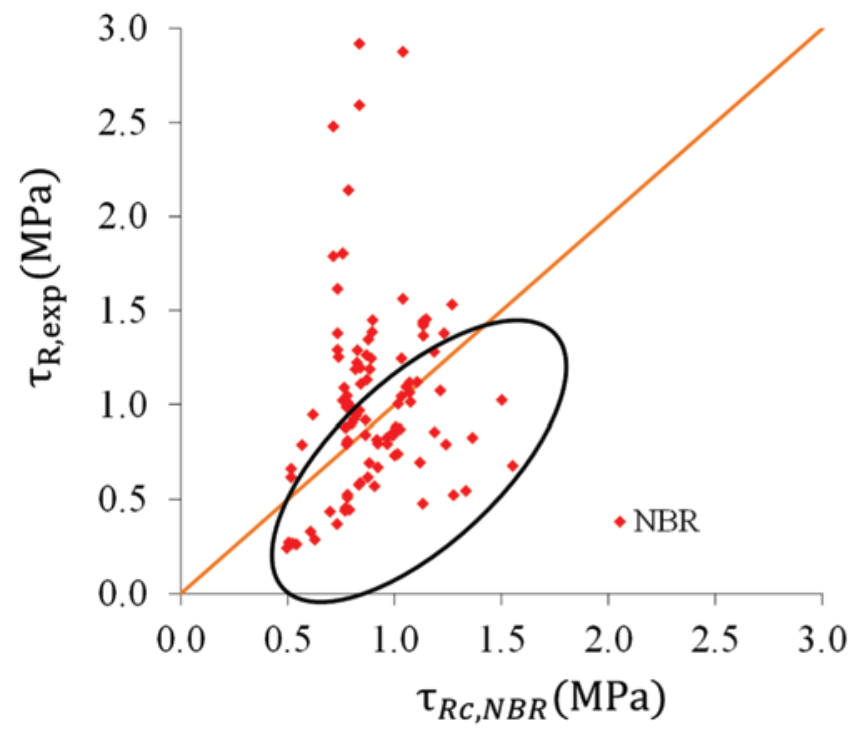

a)

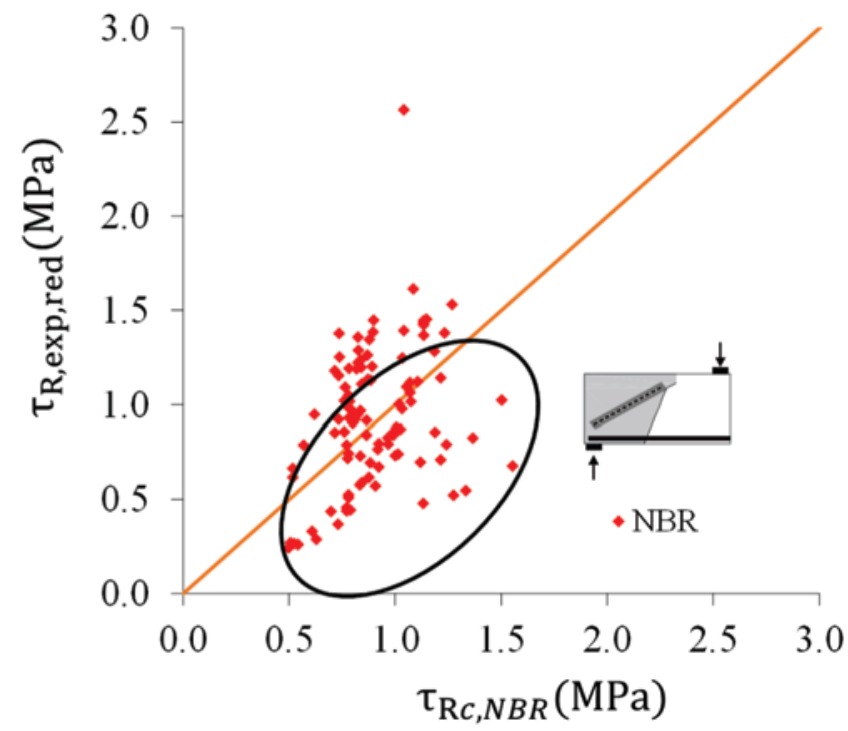

b)

\section{Figure 13}

Evaluation of the punching capacity model according to ABNT NBR 6118:2014 $\left(\gamma_{c}=1\right)$

a) Without $\beta_{\mathrm{EC}}$ and b) With $\beta_{\mathrm{EC}}$ 


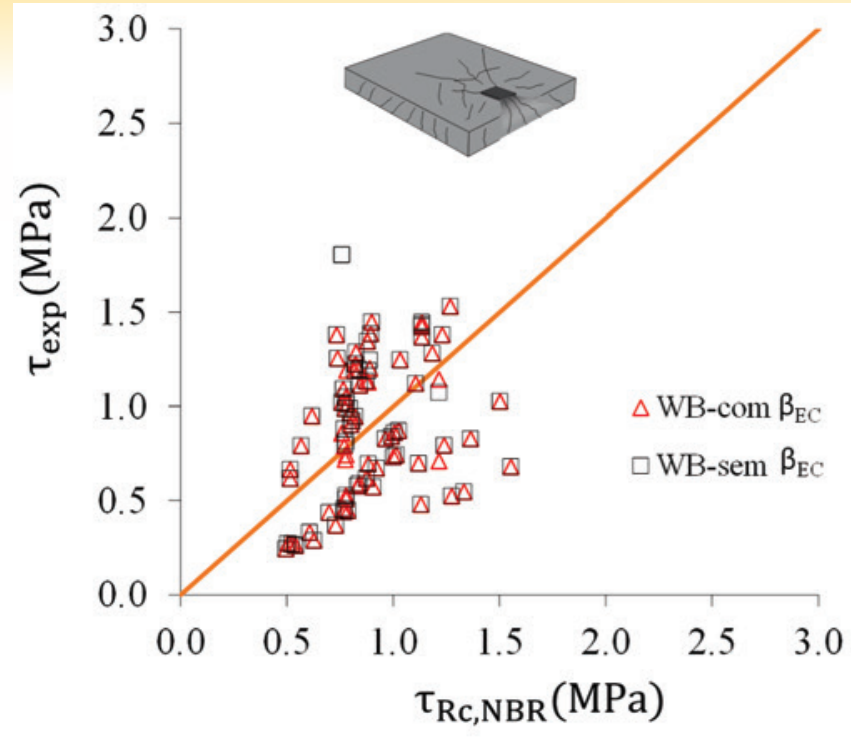

a)

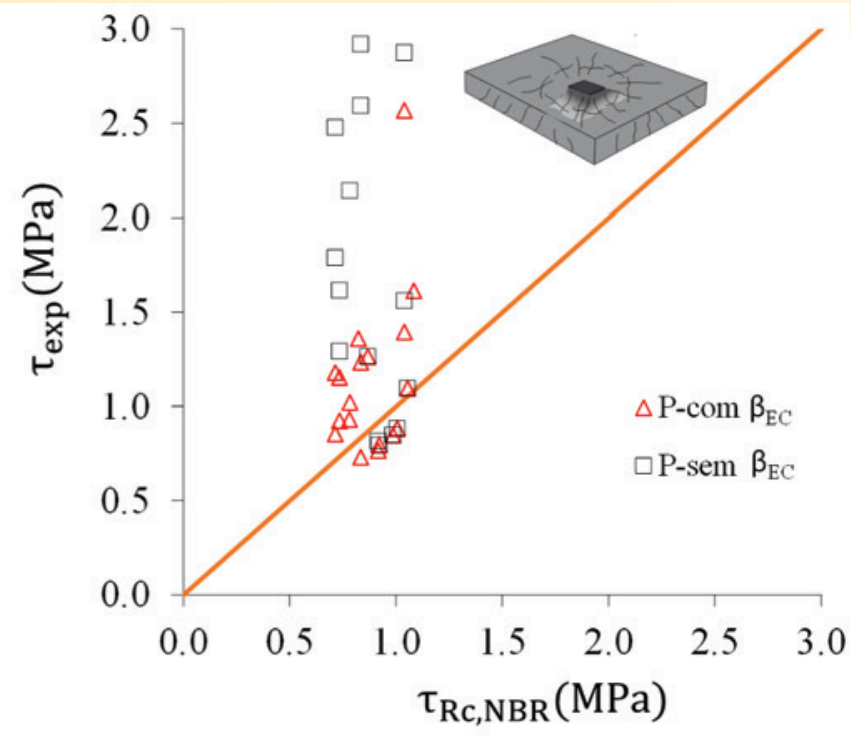

b)

\section{Figure 14}

Evaluation of the punching model of ABNT NBR 6118: 2014 according to failure mode in the experiment $\left(\gamma_{c}=1\right)$ : a) Wide Beams, b) Punching

$\beta_{\mathrm{EC}}$, to reduce the shear stress in the critical perimeter, in the case of partially distributed loads close to supports $\left(a_{v} \leq 2 d\right)$ due to the direct load transfer towards the support by strut action or arching effect. Although this is a common practice in analyzes of one-way shear strength of beams, just a few studies deal with this practice in the case of punching capacity analysis.

In Figure 13 it is observed that the coefficient $\beta_{\mathrm{EC}}$ significantly improved the level of approximation of the punching approach according to the database analyzed, with the ratio $\tau_{\text {exp }} / \tau_{R, N B R}$ being improved from $\mu=1,34$ to $\mu=1,04$ and followed by a reduction of the coefficient of variation from $v=79,08 \%$ to $v=37,10 \%$. However, as the number of unsafe predictions (calculated punching capacity greater than the experimental one) was high, perhaps the analysis of punching capacity is not the most suitable in the case of slabs subject to loads partially distributed close to the support. As this result may have been influenced by the small number of experiments that presented a punching failure mode (18/118), a more detailed analysis according to the failure mode of the experimental models is essential.

\subsubsection{Failure mode}

Figure 14 illustrates the level of approximation of the punching approach recommended by the ABNT NBR 6118:2014 applied to elements that failed by punching $(P)$ and as wide beams (WB). From Figure 14a it was observed that the predictions of punching capacity in the elements that presented a punching failure were more conservative $\left(\tau_{\text {exp,red }} / \tau_{R, N B R}\right.$ with $\mu=1,30$ and $v=31,42 \%)$ compared to the elements that failed as wide beams $\left(\tau_{\text {exp,red }} / \tau_{R, N B R}\right.$ with $\mu=0,99$ and $\left.v=38,81 \%\right)$. Furthermore, from Figure $14 a$ it was observed that, considering or not the coefficient $\beta_{\mathrm{EC}}$, the application of the punching capacity model to the elements that failed as wide beams was quite critical, with a percentage of unsafe predictions $\left(\tau_{\exp }<\tau_{\text {cal, NBR }}\right)$ ranging from $42 \%$ to $47 \%$. In other words, although the ratio $\tau_{\text {exp, red }} / \tau_{R, N B R}$ had an average value close to unity $(\mu=0.99)$, the coefficient of variation of $38.81 \%$ decreased the safety of the approach. As in the case of partially distributed loads close to support the most frequent failure mode is the one of wide beams, the application of the punching model in these cases can be considered unsafe. In Figure 14b it was observed that the elements that failed by punching presented a $\tau_{\exp } / \tau_{\mathrm{R}, \mathrm{NBR}}$ ratio closer to the unit when considering the coefficient $\beta_{\mathrm{EC}}$, with the mean value of the ratio between experimental and theoretical results $\mu=2,50$ being reduced to $\mu=1,30$. In addition, the coefficient of variation, which measures the dispersion between experimental and theoretical results, also reduced from $v=63.26 \%$ to $v=31.42 \%$. However, the dispersion remained can be considered still high.

\subsubsection{Effect of specific parameters}

Figure 15 presents the level of approximation of the ratio $\tau_{\text {exp, red }} / \tau_{R, \text { calc,NBR }}$, taking into account the reducing load factor $\beta_{E C}$ to loads near of supports, according to the compressive strength of concrete $f_{c}$ (Figure 15a), ratio of flexural reinforcement $\rho_{\ell}$ (Figure $15 b)$, ratio $a_{v} / d_{\ell}$ (Figure $15 c$ ) and effective depth to longitudinal reinforcement $d_{\ell}$ (Figure 15d).

As in the case of the approach with the one-way slabs model or slab strips, some difficulty was observed in identifying trends of results according to the parameters evaluated due to the great scatter of the results. In the case of Figure 15 this was even more difficult, probably due to the dependence of the slab characteristic in both directions. In analyses using the mean value $d=\left(d_{l}+d_{t}\right) / 2$ and $\rho=\sqrt{\rho_{\mid} \cdot \rho_{t}}$ some difficulty was also identified. From Figure 15 , only a tendency of less dispersion of the results was observed with the increase of the compressive strength of the concrete (Figure 15a) as with increasing of the ratio of flexural reinforcement (Figure 15d), but which may have been influenced by the reduction in the number of experimental results in these ranges. Figure 15 shows that the scatter of predictions of resistance with the punching approach was more pronounced for the same parameters evaluated with the one-way model. Thus, it was not possible to state behavior trends in the punching model without further experiments. 


\subsubsection{Load Position}

Figure 16 shows the level of accuracy of the ratio $\tau_{\text {exp,red }} / \tau_{R, \text { calc,NBR }}$ according to the experimental shear stress at the critical perimeter and the load position on the slabs. Figure 16a shows that the punching model provides more conservative results for the higher loadings, but for critical perimeter with shear stresses less than $0.7 \mathrm{MPa}$ the model presents critical results. In addition, the results obtained showed that for loads close to the support

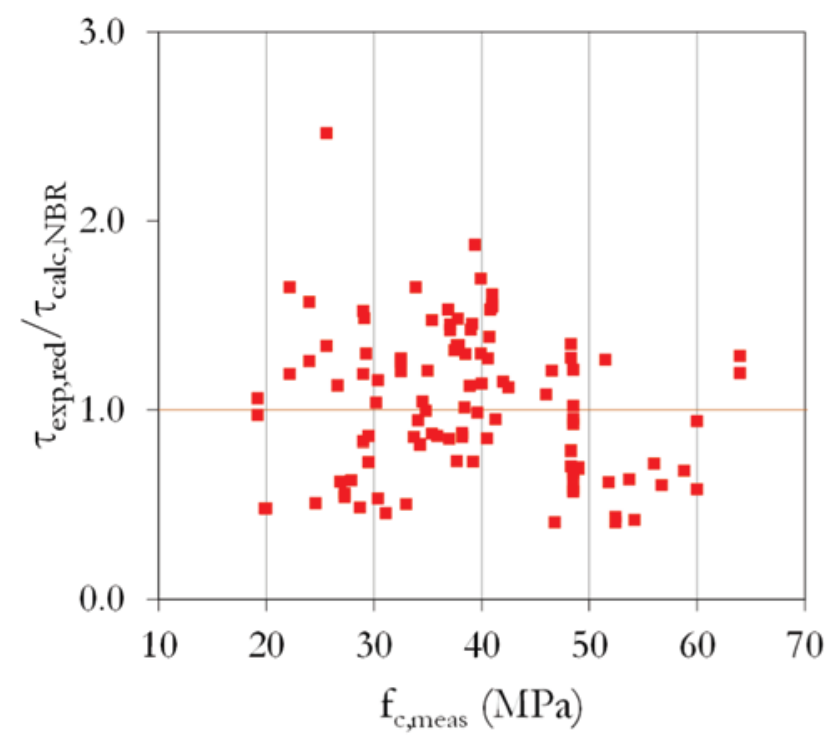

a)

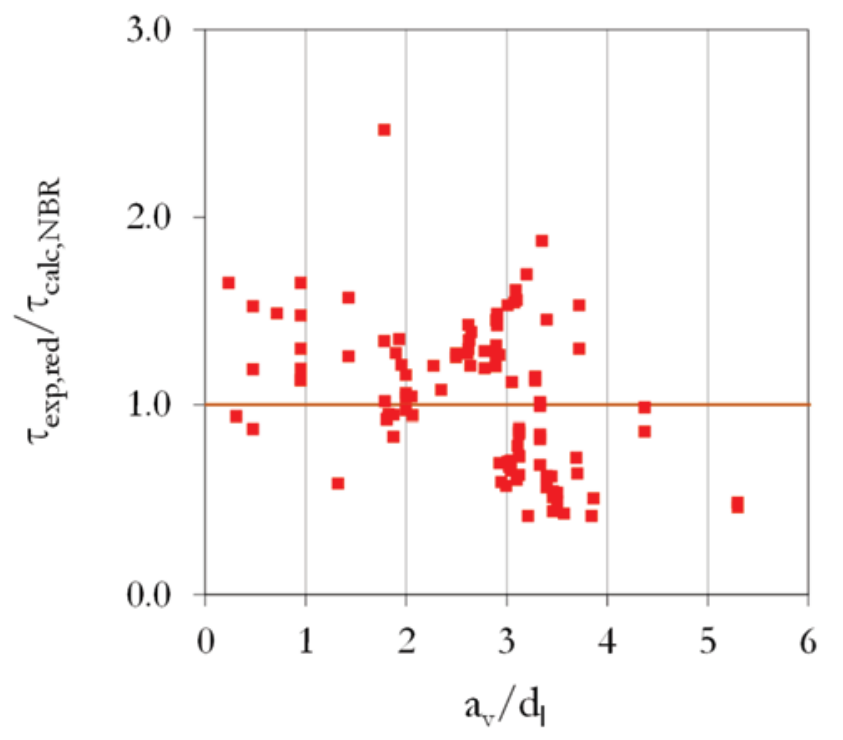

c) in regions of slab continuity the ratio $\tau_{\text {exp,red }} / \tau_{R, \text { calc,NBR }}$ was more conservative ( $\mu=1,47$ and $v=13,65 \%)$ than in the cases of loads close to the support of cantilever slabs ( $\mu=0,92$ and $v=37,80 \%$ ) and simply supported slabs ( $\mu=1,05$ and $v=37,64 \%)$. The same behavior among different load positions was observed in Figure $16 \mathrm{~b}$, which illustrates the higher scatter of the results for loads close to simple supports (SS) and the lower scatter obtained continuous slabs (CS), but this time according to the thickness of the slabs.

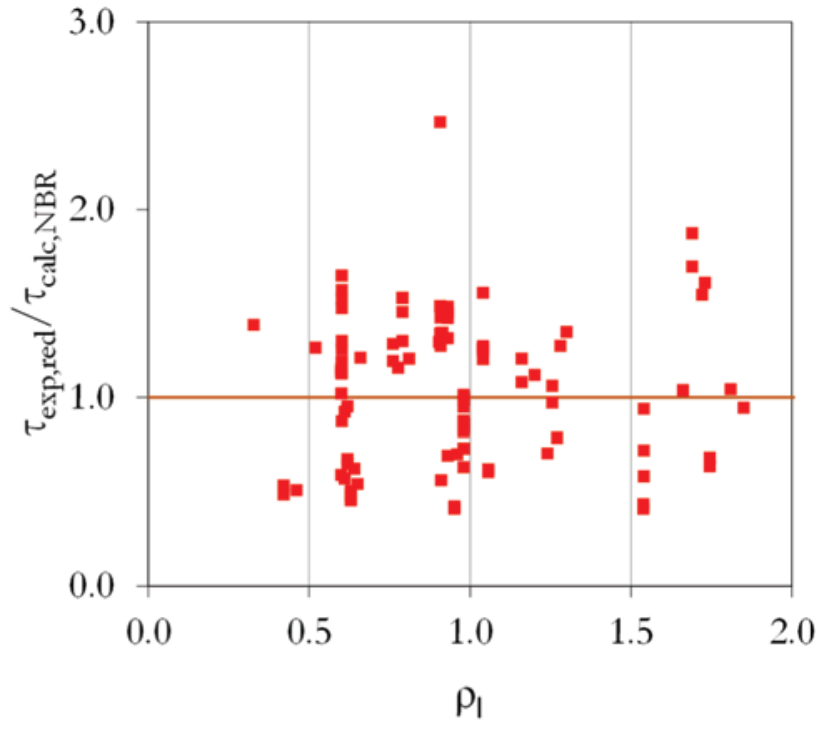

b)

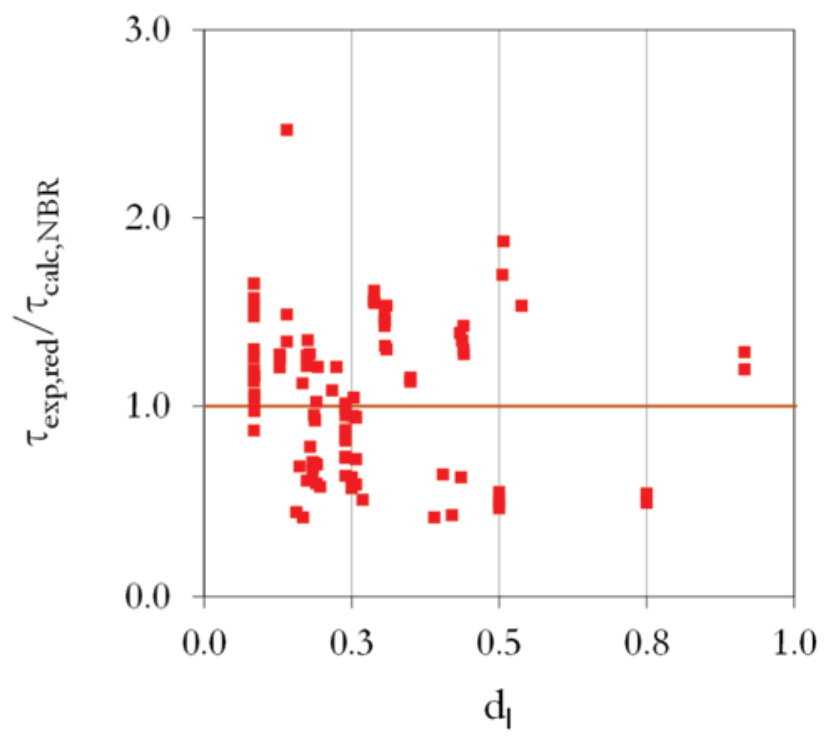

d)

\section{Figure 15}

$\tau_{\text {exp }} / \tau_{\text {calc NBR }}$ ratio $\left(\gamma_{c}=1\right)$ according to ABNT NBR 61 18:2014 with: a) compressive strength of concrete $f_{c^{\prime}}$ b) Ratio of flexural reinforcement $\left.\rho_{l}, c\right) a_{v} / d_{1}$ ratio and $d$ ) Effective depth of longitudinal reinforcement $d_{1}$ 


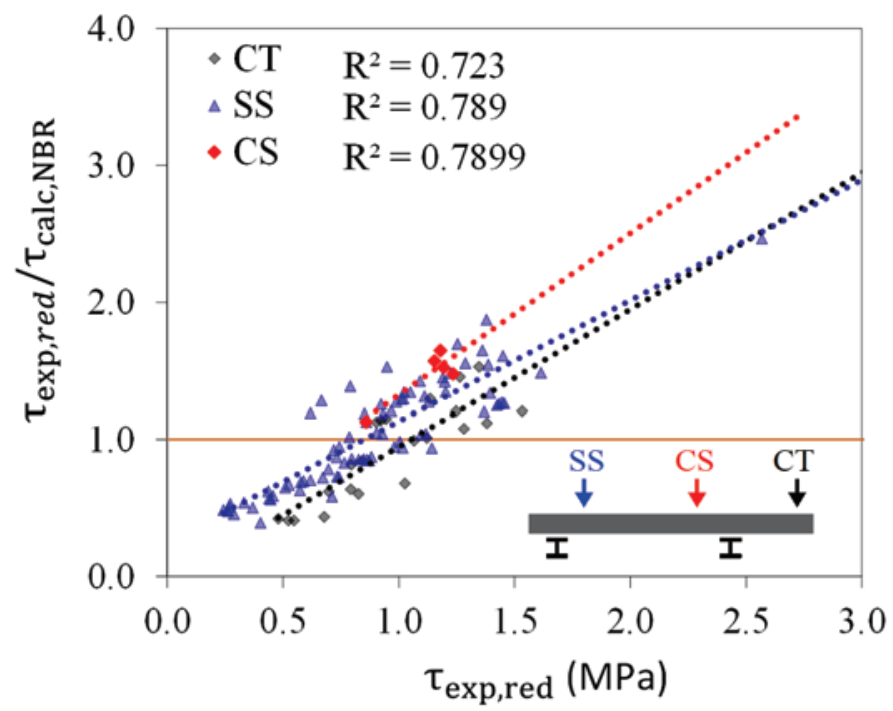

a)

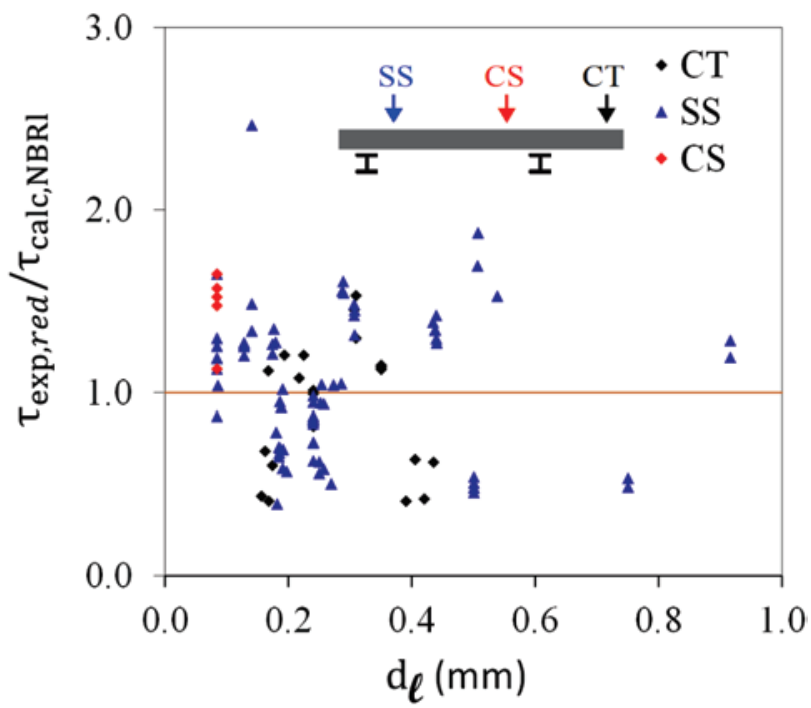

b)

\section{Figure 16}

Level of accuracy of the punching model from ABNT NBR $6118: 2014\left(\gamma_{c}=1\right)$ according to the static system and: a) shear stress at the critical perimeter and b) slab thickness

\subsection{Summary of results}

The Table 2 summarizes the results obtained according to the approaches of shear strength in one-way slabs and punching capacity verification available in ABNT NBR 6118: 2014 [11] and Eurocode 2 [18]. Among the main results, Table 2 pointed out that the French approach $\left(\mathrm{b}_{\text {eff } 2}\right)$ and the consideration of the reduction of shear force with $\beta_{E C}$, for loads distributed in small areas near the support, increase significantly the level of prediction of the oneway model of calculation of shear strength, both in the European and Brazilian codes, reducing the coefficient of variation of the ratio $\mathrm{V}_{\text {exp }} / \mathrm{V}_{\mathrm{NBR}}$ from $124,5 \%$ to $29,76 \%$ and with the average value of the ratio $V_{\text {exp }} / V_{\text {NBR }}$ being reduced from 2,00 to 1,02 . However, the precision and accuracy gain in the model is controversial since, due to the large coefficient of variation, the model resulted in a high number of unsafe predictions of the shear strength (58\%), that is, with $\mathrm{V}_{\text {exp }} / \mathrm{V}_{\text {calc,NBR }}<1$. In the European code, comparatively, although the average value of $\mathrm{V}_{\text {exp,red, } \mathrm{EC}} / \mathrm{V}_{\mathrm{R}, \mathrm{c}, \mathrm{beff} 2}$ was 1,35 , the percentage of unsafe predictions of shear strength was lower (19\%).

From Table 2 it can still be distinguished that there is a difference of results according to the shear strength model depending on the experimental failure mode of the elements. For example, by applying the Brazilian model of shear strength in one-way slabs to the elements that failed by punching, the results of $\mathrm{V}_{\text {exp,red }} / \mathrm{V}_{\mathrm{NBR}, \text { befi2 }}$ were

\section{Table 2}

Results obtained with the one-way and two-way approaches to shear resistance of slabs according to ABNT NBR 6118: 2014 [11] and Eurocode 2 [18]

\begin{tabular}{|c|c|c|c|c|c|c|c|c|c|c|}
\hline & $\frac{V_{\text {exp }}}{V_{\text {NBR,beffl }}}$ & $\frac{V_{\text {exp,red }}}{V_{E C, \text { beffl }}}$ & $\frac{V_{\text {exp,red }}}{V_{\text {NBR,beffl }}}$ & $\frac{V_{\text {exp }}}{V_{\text {NBR, beff2 }}}$ & $\frac{V_{\text {exp,red }}}{V_{E C, \text { beft2 }}}$ & $\frac{V_{\text {exp,red }}}{V_{\text {NBR,beft2 }}}$ & $\frac{\tau_{\exp }}{\tau_{\text {calc,NBR }}}$ & $\frac{\tau_{\text {exp,red }}}{\tau_{\text {calc,NBR }}}$ & $\frac{\tau_{\text {exp }}}{\tau_{\text {calc }, \mathrm{EC}}}$ & $\frac{\tau_{\text {exp,red }}}{\tau_{\text {calc,EC }}}$ \\
\hline \multicolumn{11}{|c|}{ Punção (P) } \\
\hline$\mu$ & 5,13 & 3,32 & 2,54 & 2,64 & 1,82 & 1,42 & 2.50 & 1.30 & 1.75 & 1.06 \\
\hline$\sigma$ & 3,65 & 1,19 & 0,76 & 1,44 & 0,51 & 0,38 & 1.58 & 0.41 & 0.71 & 0.48 \\
\hline$v$ & $71,09 \%$ & $35,74 \%$ & $30,01 \%$ & $54,61 \%$ & $28,21 \%$ & $26,57 \%$ & $63.26 \%$ & $31.42 \%$ & $40.92 \%$ & $45.13 \%$ \\
\hline \multicolumn{11}{|c|}{ Viga larga (wide beam - WB) } \\
\hline$\mu$ & 1,31 & 1,38 & 1,04 & 1,07 & 1,23 & 0,92 & 1.12 & 0.99 & 1.12 & 1.04 \\
\hline$\sigma$ & 1,64 & 0,56 & 0,40 & 0,76 & 0,27 & 0,19 & 0.79 & 0.38 & 0.47 & 0.44 \\
\hline$v$ & $125,8 \%$ & $40,08 \%$ & $38,25 \%$ & $71,11 \%$ & $22,09 \%$ & $20,29 \%$ & $69.91 \%$ & $38.81 \%$ & $41.87 \%$ & $42.57 \%$ \\
\hline \multicolumn{11}{|c|}{ Todos } \\
\hline$\mu$ & 2,00 & 1,79 & 1,37 & 1,34 & 1,34 & 1,02 & 1.34 & 1.04 & 1.23 & 1.07 \\
\hline$\sigma$ & 2,50 & 1,05 & 0,79 & 1,06 & 0,40 & 0,30 & 1.06 & 0.39 & 0.56 & 0.45 \\
\hline$v$ & $124,5 \%$ & $58,70 \%$ & $57,72 \%$ & $78,86 \%$ & $29,76 \%$ & $29,73 \%$ & $79.08 \%$ & $37.10 \%$ & $45.20 \%$ & $41.87 \%$ \\
\hline
\end{tabular}


more conservative $(\mu=1,42$ and $v=26,57 \%)$ and with lower failure percentage than the ones obtained by applying the method to elements that presented failure in a one-way mode as wide beams or slab strips ( $\mu=0.92$ and $\nu=20.29 \%$ ).

Regarding the models of punching capacity, it was observed that the relation $\tau_{\exp } / \tau_{R, \text { calc,NBR }}$ showed pronounced differences of result with the consideration or not of the coefficient $\beta_{\mathrm{EC}}$, especially in those elements that presented a punching failure model. In these cases, the average value of the $\tau_{\text {exp }} / \tau_{R, \text { calc NBR }}$ varied from 2.50 to 1.30 and the coefficient of variation decreased from $63.26 \%$ to $31.42 \%$. Comparatively, the European standard also improved the accuracy with consideration of the $\beta_{\mathrm{EC}}$ factor, but the coefficient of variation increased from $40.92 \%$ to $45.13 \%$ with $\beta_{\mathrm{EC}}$. In the case of elements that failed as wide beams, although the ratio was close to 1 with both the Brazilian and European standard models, the high coefficient of variation and the excess of capacity predictions contrary to the safety indicated that this verification approach would not be the most adequate.

\section{Conclusions}

The text presents a study with focus on the evaluation of the level of precision of the Brazilian standard regarding the approaches of shear strength in the case of concentrated loads in small areas near the support, comparing in the end the results with those provided by the corresponding European code. From the results, it can be concluded that:

- The model of shear strength in the Brazilian standard to linear elements, as currently provided, presented unsatisfactory results of precision in the case of loads distributed in small areas near the support with the one-way approach $\left(\mathrm{V}_{\text {exp }} \mathrm{N}_{\mathrm{NBR}, \text { beff } 1}\right.$ with $\mu=2,00$ and $\nu=124,5 \%$ and $V_{\text {exp }} / V_{\text {NBR,beff2 }}$ with $\mu=1,34$ and $\nu=78,68 \%$ );

- Consideration of the reduction of the shear force in the case of loads distributed in small areas close to the support by the factor $\beta_{\mathrm{EC}}$, as well as the use of the French definition of the effective width, result in a better level of accuracy with regard to $V_{\text {exp }} / V_{\text {NBR }}(\mu=1,02$ and $v=29,73 \%)$. Meantime, due to the large number of unsafe predictions of resistance with this procedure $\left(58 \%\right.$ of $\left.V_{\text {exp }} N_{\text {calc }}<1\right)$, its incorporation into the formulation provided by the Brazilian code is still questionable;

- Regarding the Brazilian model of punching capacity, it was observed that taking into account the reduction of shear force in the case of loads close to the support significantly improved the accuracy and precision of the ratio $\tau_{\text {exp }} / \tau_{R, N B R}$, regardless of the failure mode of the experiments. However, due to the still high coefficient of variation (>35\%) and a large number of unsafe resistance predictions, the verification of punching capacity in the case of partially distributed loads close to the support proved not to be the most adequate, especially in the possibility of failure as a large beam.

\section{Acknowledgments}

The authors gratefully acknowledge the financial support provided by the Coordination for the Improvement of Higher Education Personnel (CAPES) and the National Council for Scientific and Technological Development (CNPq).

\section{Bibliographic references}

[1] NATÁRIO, F., RUIZ, M. F., MUTTONI, A. Shear strength of RC slabs under concentrated loads near clamped linear supports. Engineering structures, 76, 2014, p. 10-23.

[2] RUIZ, M.F, MUTTONI, A., SAGASETA, J. Shear strength of concrete members without transverse reinforcement: A mechanical approach to consistently account for size and strain effects. Engineering Structures, v. 99, 2015, p. 360-372.

[3] LANTSOGHT, E. O., VAN DER VEEN, C., WALRAVEN, J. C., DE BOER, A. Transition from one-way to two-way shear in slabs under concentrated loads. Magazine of Concrete Research, v.67, n.17, 2015, p. 909-922.

[4] HUBER, P., KOLLEGGER, J. (2015) Shear behavior of existing bridges without and with a minimum amount of shear reinforcement. In: Concrete - Innovation and Design, fib Symposium, Copenhagen, 2015.

[5] LANTSOGHT, E. O. L., VAN DER VEEN, C., WALRAVEN, J., DE BOER, A. Recommendations for the shear assessment of reinforced concrete slab bridges from experiments. Structural Engineering International, v.23, n.4, 2013, p. 418-426.

[6] LANTSOGHT, E. O., VAN DER VEEN, C., WALRAVEN, J., DE BOER, A. Experimental investigation on shear capacity of reinforced concrete slabs with plain bars and slabs on elastomeric bearings. Engineering Structures, v. 103, 2015, p. 1-14.

[7] BUI, T. T., NANA, W. S. A., ABOURI, S., LIMAM, A., TEDOLDI, B., ROURE, T. Influence of uniaxial tension and compression on shear strength of concrete slabs without shear reinforcement under concentrated loads. Construction and Building Materials, v.146, 2017, p. 86-101.

[8] NATÁRIO, F., RUIZ, M. F., MUTTONI, A. Experimental investigation on fatigue of concrete cantilever bridge deck slabs subjected to concentrated loads. Engineering structures, v.89, 2015, p.191-203.

[9] REISSEN, K., HEGGER, J. Experimental investigations on the effective width for shear of single span bridge deck slabs. Betonund Stahlbetonbau, v. 108, n. 2, 2013, p. 96-103 (in germany).

[10] REISSEN, K., HEGGER, J. Experimental investigations on the shear-bearing behaviour of bridge deck cantilever slabs under wheel loads. Beton- und Stahlbetonbau, v. 108, 2013, p. 315-324 (in germany).

[11] ASSOCIAÇÃO BRASILEIRA DE NORMAS TÉCNICAS. NBR 6118: Projeto de Estruturas de Concreto - Procedimento. Rio de Janeiro, 2014.

[12] NANA, W. S. A., BUI, T. T., LIMAM, A., ABOURI, S. Experimental and numerical modelling of shear behaviour of fullscale RC slabs under concentrated loads. In Structures. v. 10, 2017, p. 96-116.

[13] LANTSOGHT, E. O., VAN DER VEEN, C., WALRAVEN, J. C., DE BOER, A. Database of wide concrete members failing in shear. Magazine of Concrete Research, v. 67, n. 1, 2015, p. 33-52.

[14] NORMCOMISSIE 351001 - NEN 6720 Technische Grondslagen voor Bouwvoorschriften, Voorschriften Beton TGB 1990Constructieve Eisen em Rekenmethoden (VBC 1995), 1995.

[15] FD P 18-717. Eurocode 2 - Calcul des structures en béton Guide d'application des normes NF EN 1992, 2013. 
[16] fib. Model Code 2010: final draft. Lausanne Internationa Federation Structure Concrete, 2012.

[17] ASSOCIAÇÃO BRASILEIRA DE NORMAS TÉCNICAS. NBR 6118: Projeto e execução de obras de concreto armado. Rio de Janeiro, 1980.

[18] CEN. Eurocode 2 - Design of Concrete Structures: Part 1-1 General Rules and Rules for Buildings, NEN-EN 1992-11, Comité Européen de Normalisation, Brussels, Belgium, 2004, 229 p.

[19] ACl Committee 318: Building Code Requirements for Structural Concrete and Commentary (ACI 318-14), 2014.

[20] YANG, Y, UIJL, J, WALRAVEN, J. Critical shear displacement theory: on the way to extending the scope of shear design and assessment for members without shear reinforcement. Structural Concrete, v. 17, n. 5, 2016, p. 790-798.

[21] LEONHARDT, F., WALTHER, R. Shear tests on beams with and without shear reinforcement (in germany, Schubversuche an einfeldrigen Stahlbetonbalken mit und ohne Schubbewehrung), Deutscher Ausschuss für Stahlbeton, Heft 151, 1962, 83 p.

[22] KANI, G. N. J. Basic Facts Concerning Shear Failure, $\mathrm{ACl}$ Journal Proceedings, Vol. 63, N 6, 1966, p. 675-692.

[23] MUTTONI, A., FERNÁNDEZ RUIZ, M. Shear in slabs and beams: should they be treated in the same way?. Fédération Internationale du Béton (fib) Bulletin, $N^{\circ} 57,2010$, p. 105-128.

[24] REGAN, P.E. Shear Resistance of Concrete Slabs at Concentrated Loads Close to Supports. Polytechnic of Central London, London, UK, 1982, pp. 1-24.

[25] SHERWOOD, E.G., LUBELL, A.S., BENTZ, E.C., COLLINS, M.P. One-way Shear Strength of Thick Slabs and Wide Beams, ACI Structural Journal, v. 103, n. 6, 2006, p.794-802.

[26] VAZ RODRIGUES, R., MUTTONI, A., OLIVIER, O. Large Scale Tests on Bridge Slabs Cantilevers Subjected to Traffic Loads. In: Proceedings of the 2nd international Congress, Fédération Internationale du Béton, Naples, Italy, 2006, 10 p.

[27] JÄGER, T. Shear strength and deformation capacity of reinforced concrete slabs. In: Proceedings of the 4th International PhD Symposium in Civil Engineering, Munich, Germany. Fédération internationale du béton, Lausanne, Switzerland, 2002, p. 280-286.

[28] JÄGER, T. Experiments on the Shear and Deformation Capacity of Reinforced Concrete Slabs. Monograph, ETH Zurich, Zurich, Switzerland (in German), 2005.

[29] JÄGER, T. Shear and Deformation Capacity of Reinforced Concrete Slabs. PhD thesis, ETH Zurich, Zurich, Switzerland, 2007 (in germany).

[30] GRAF, O. Experiments on the capacity of concrete slabs subjected to concentrated loads close to a support. Deutscher Ausschuss für Eisenbeton, v. 73, 1933, p. 10-16 (in germany).

[31] RICHART, F.E., KLUGE, R.W. Tests of Reinforced Concrete Slabs Subjected to Concentrated Loads: A Report of an Investigation. Engineering Experiment Station, University of Illinois, Urbana, IL, USA, Bulletin 314, 1939.

[32] DIAZ DE COSSIO, R et al. Shear and diagonal tension discussion. ACl Journal Proceedings, v. 59, n.11, 1962, p. 1323-1339.
[33] RAJAGOPALAN, K.S., FERGUSON, P.M. Exploratory shear tests emphasizing percentage of longitudinal steel. ACl Journal Proceedings, v. 65, n.8, 1968, p. 634-638.

[34] ASTER, H., KOCH, R. Shear capacity of deep concrete slabs. Beton- und Stahlbetonbau, v. 69, n. 11, 1974, p. 266-270 (in germany).

[35] HEGER, F.J., MCGRATH, T.J. Design Method for Reinforced Concrete Pipe and Box Sections. Simpson Gumpertz \& Heger, Cambridge, MA and San Francisco, CA, USA, 1980.

[36] CULLINGTON, D.W., DALY, A.F., HILL, M.E. Assessment of reinforced concrete bridges: collapse tests on Thurloxton underpass. Bridge Management, v. 3, 1996, p. 667-674.

[37] COIN, A., THONIER, H. Experiments on shear in reinforced concrete slabs (Essais sur le cisaillement des dalles en beton arme). Annales du batiment et des travaux publics, 2007, p. 7-16. (in french).

[38] OLONISAKIN A.A., ALEXANDER, S.D.B. Mechanism of shear transfer in a reinforced concrete beam. Canadian Journal of Civil Engineering, v. 26, n. 6, 1999, p. 810-817.

[39] ROMBACH, G., LATTE, S. Shear resistance of bridge decks without shear reinforcement. In: Proceedings of the International fib Symposium, 2008, p. 519-525.

[40] ROMBACH, G., LATTE, S. Shear resistance of bridge decks without transverse reinforcement. Beton-und Stahlbetonbau, v.104, n.10, 2009, p. 642-656 (in germany).

[41] BAŽANT, Z.P., KIM, J.K. Size effect in shear failure of longitudinally reinforced beams. Journal of the American Concrete Institute, v. 81 , n.5, 1984, p. 456-468. 